Foraminifera from the Kara and Greenland Seas, and Review of Arctic Studies

GEOLOGICAL SURVEY PROFESSIONAL PAPER 1070

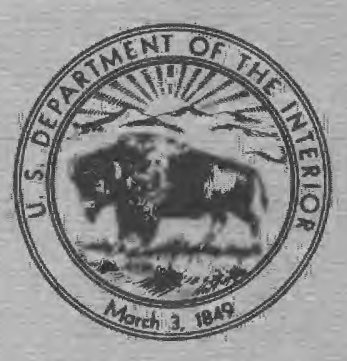




\section{Foraminifera from the Kara and Greenland Seas, and Review of Arctic Studies}

By Ruth Todd and Doris Low

GEOLOGICAL S URVEY PROFESIONAL PAPER 1070

Sparse and erratic fauna (111 species) of low diversity and strong dominances from the Continental Shelf of both seas and from slopes, basins, and rises of the Greenland Sea

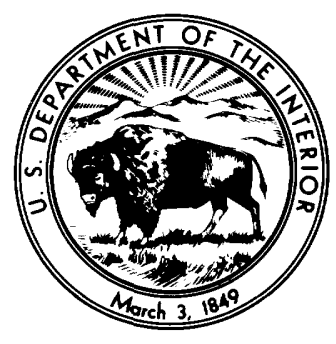

UNITED STATES GOVERNMENT PRINTING OFFICE, WASHINGTON : 1980 


\section{UNITED STATES DEPARTMENT OF THE INTERIOR}

CECIL D. ANDRUS, Secretary

\section{GEOLOGICAL SURVEY}

H. William Menard, Director

\section{Library of Congress Cataloging in Publication Data}

Todd, Ruth, 1913-

Foraminifera from the Kara and Greenland Seas, and review of Arctic studies.

(Geological Survey professional paper ; 1070)

Bibliography: p.

Includes index.

Supt. of Docs. no.: I 19.16:1067

1. Foraminifera-Kara Sea.

2. Foraminifera-Greenland Sea. I. Low, Doris, joint author. II. Title.

III. Series: United States. Geological Survey. Professional paper ; 1070.

QE772.T592 563'.1 77-608327

For sale by the Superintendent of Documents, U.S. Government Printing Office

Washington, D.C. 20402

Stock Number 024-001-03287-2 


\section{CONTENTS}

Abstract
Introduction
Previous studies in the area

\section{ILLUSTRATIONS}

[Plates 1 and 2 follow index]

Plate 1. Arenaceous Foraminifera from Kara and Greenland Seas.

2. Calcareous Foraminifera from Kara and Greenland Seas.

Figure 1. Index map

Map of Kara Sea

\section{TABLES}

TABLE 1. Distributior of species in the Kara and Greenland Seas

2. Locality and depth of bottom-sediment samples from the Kara Sea

3. Locality and depth of bottom-sediment samples from the Greenlan 



\title{
FORAMINIFERA FROM THE KARA AND GREENLAND SEAS, AND REVIEW OF ARCTIC STUDIES
}

\author{
By Ruth TODd and Doris Low
}

\begin{abstract}
Analyses of the Foraminifera found in 83 bottom sediment samples from the Kara and Greenland Seas showed a combined fauna of 111 species. All the Kara samples and half the Greenland samples were taken on the Continental Shelf at depths between 82 and $640 \mathrm{~m}$. The samples from deeper parts of the Greenland Sea were taken from continental slopes, basins, and rises, at depths mostly between 2,195 and $3,340 \mathrm{~m}$.

The sparse fauna is erratic in distribution and has a low diversity but a uniformity of character over large areas. Many of the species appear to be eurybathyal. Many samples are strongly dominated by one or more species. Large robust arenaceous and porcellaneous species constitute a significant part of the population.
\end{abstract}

\section{INTRODUCTION}

Two lots of bottom sediment samples-47 from the northern and western parts of the Kara Sea and 36 from the northern part of the Greenland Sea-were selected for Foraminifera analysis from collections made during oceanographic surveys in the late summer of 1965 (fig. 1 and table 1). These surveys were conducted by personnel from the U.S. Naval Oceanographic Office on board the U.S. Coast Guard Cutter Northwind (WAGB-282) in the Kara Sea from July 25 to September 29, 1965 and the U.S.S. Edisto (AGB-2) in the Greenland Sea from August 23 to September 12, 1965.

Most of the 47 Kara Sea samples were concentrated in an area between about lat $77^{\circ} 30^{\prime}$ and $81^{\circ} 30^{\prime}$ $\mathrm{N}$. and between about long $67^{\circ}$ and $88^{\circ} \mathrm{E}$., but a few were taken from east of Novaya Zemlya as far south as lat $72^{\circ}$ N. (figs. 1, 2, and table 2). Depths sampled in the Kara Sea ranged from 82 to $640 \mathrm{~m}$; most of them were between 188 and $541 \mathrm{~m}$. Because the depths did not vary extremely and because depth did not seem to affect the foraminifer assemblages, we have arranged the samples in approximate order of geographic sequence from northeast to southwest.

On table 1 we have grouped the samples from Kara Sea as follows:
Arctic Ocean, northeast of Severnaya Zemlya (North Land) ( 1 sample at $265 \mathrm{~m}$ )

Off Taymyr Peninsula, between Taymyr Peninsula and North Land (1 sample at $82 \mathrm{~m}$ )

West of North Land (11 samples ranging in depth from 188 to $412 \mathrm{~m}$ )

East of Franz Josef Land (18 samples ranging in depth from 216 to $640 \mathrm{~m}$ )

South of Franz Josef Land toward Novaya Zemlya ( 7 samples ranging in depth from 251 to $485 \mathrm{~m}$ )

Bordering Novaya Zemlya (9 samples ranging in depth from 223 to $499 \mathrm{~m}$ )

These groupings in the Kara Sea have little to unite them and set them apart from each of the other regional groupings except that the more southerly samples, toward Novaya Zemlya, show a lack or a decrease of Reophax nodulosus, Hyperammina elongata, Cribrostomoides subglobosus, and Aschemonella scabra.

In general, each individual fauna is small in number of species, and most faunas are dominated by one or several species. The overall picture does not show a consistent presence of many species, such as is characteristic of warmer waters. The most persistent species on the Continental Shelf are Psammosphaera fusca, Reophax scorpiurus, and Trochammina nana, and the first two of these are in positions of dominance in most of the samples. Cribrostomoides crassimargo and Saccorhiza ramosa are fairly consistent but very scattered east of Franz Josef Land; they are not dominant, except that $S$. ramosa shares dominance with other species in several of the southern samples along Novaya Zemlya.

A total of 36 samples from the Greenland Sea were studied, most of them found between approximately lat $71^{\circ}$ and $78^{\circ} \mathrm{N}$. and long $20^{\circ}$ and $1^{\circ} \mathrm{W}$. (table 3 ). Three others were found near Spitsbergen at about lat $80^{\circ} \mathrm{N}$. and between long $1^{\circ}$ and $4^{\circ} \mathrm{E}$. Depths sampled range from 45 to 1,825 fathoms (about 82 to $3,340 \mathrm{~m}$ ). Those taken on the Conti- 


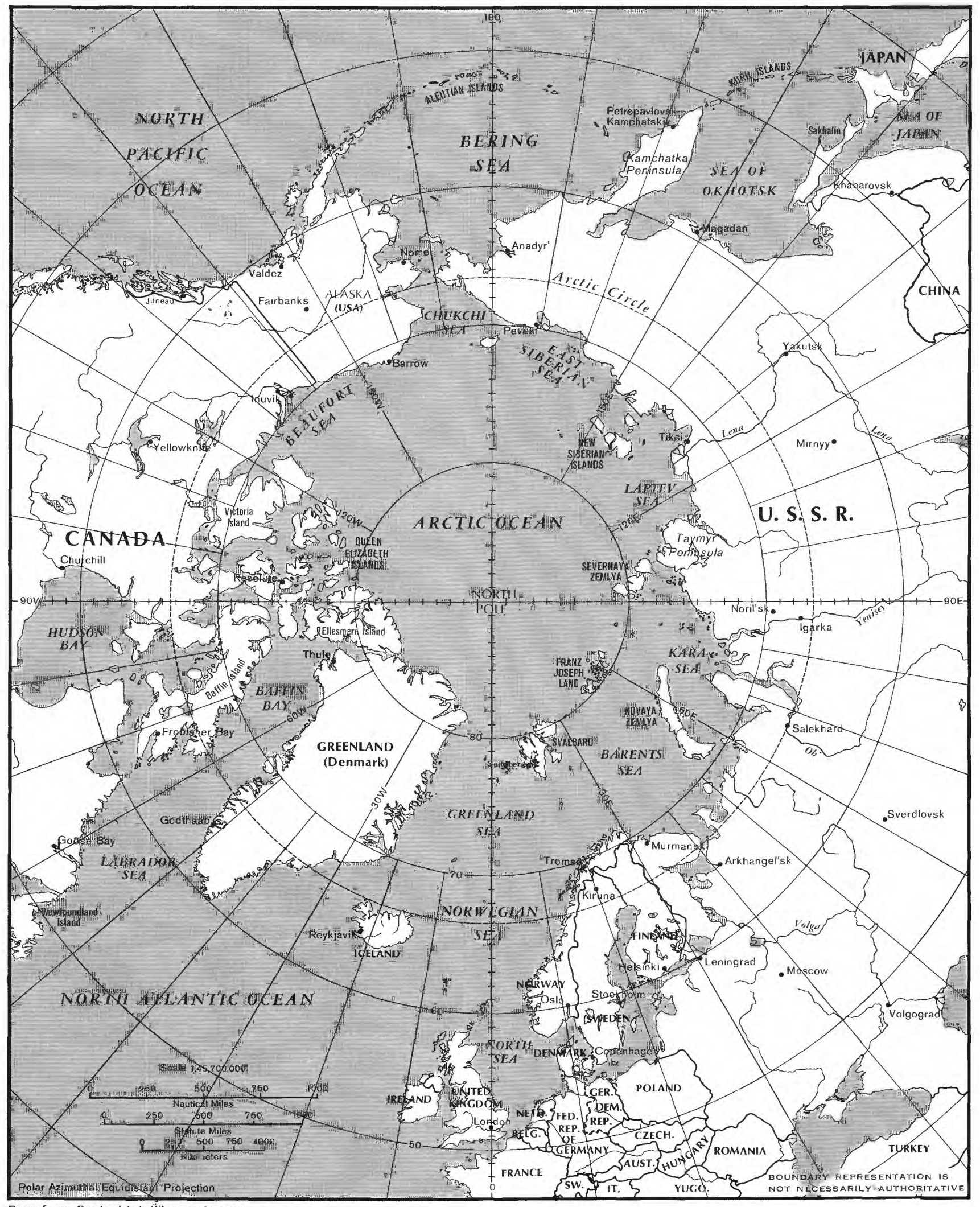

Base from Central intelligence Agency

FIGURE 1.-Index map of the north polar region showing place names mentioned in text. 


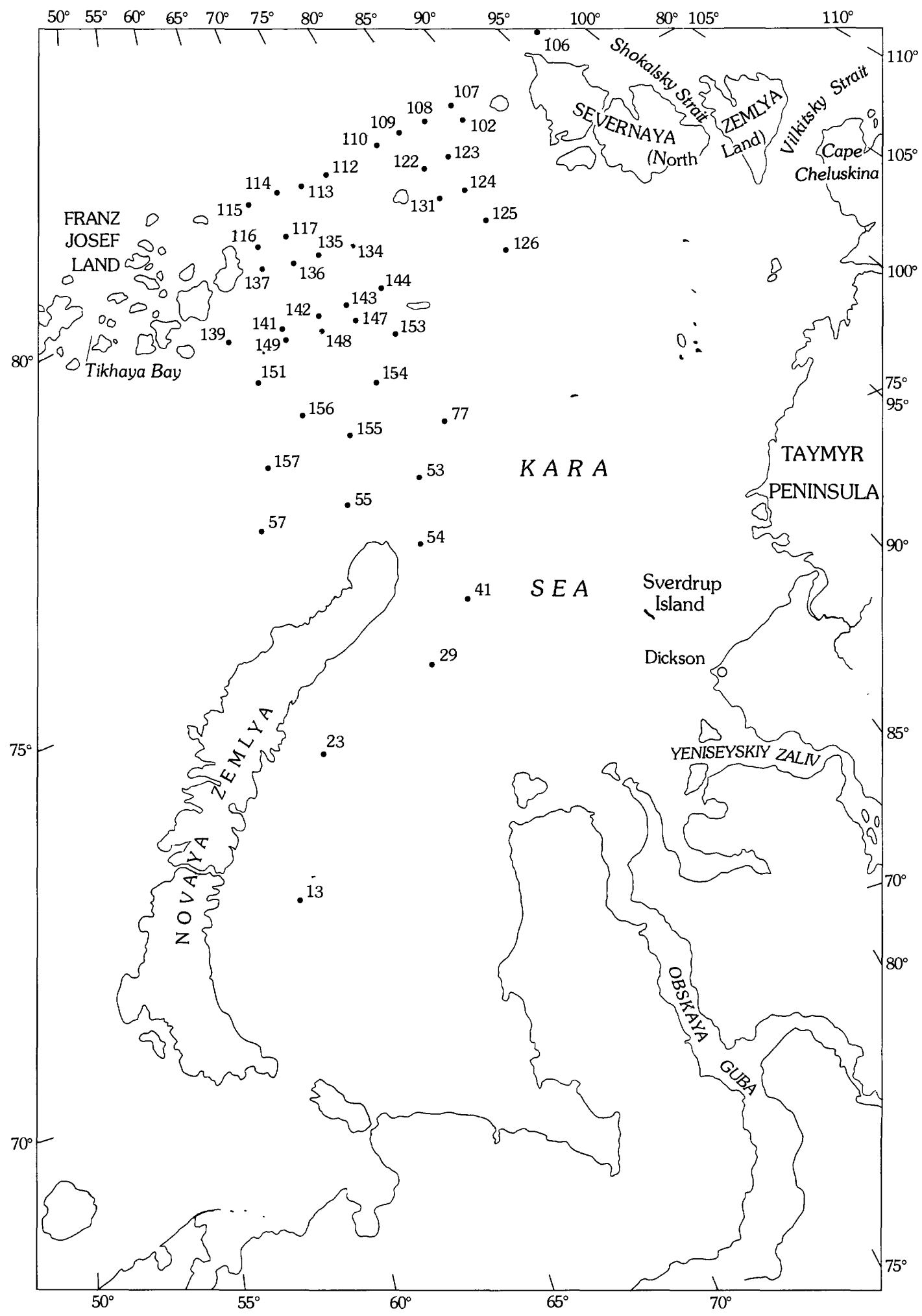

FiguRE 2.-Map of the Kara Sea showing the location of bottom sediment samples. 
TABLE 1.-Distribution of species in the Kara and Greenland Seas

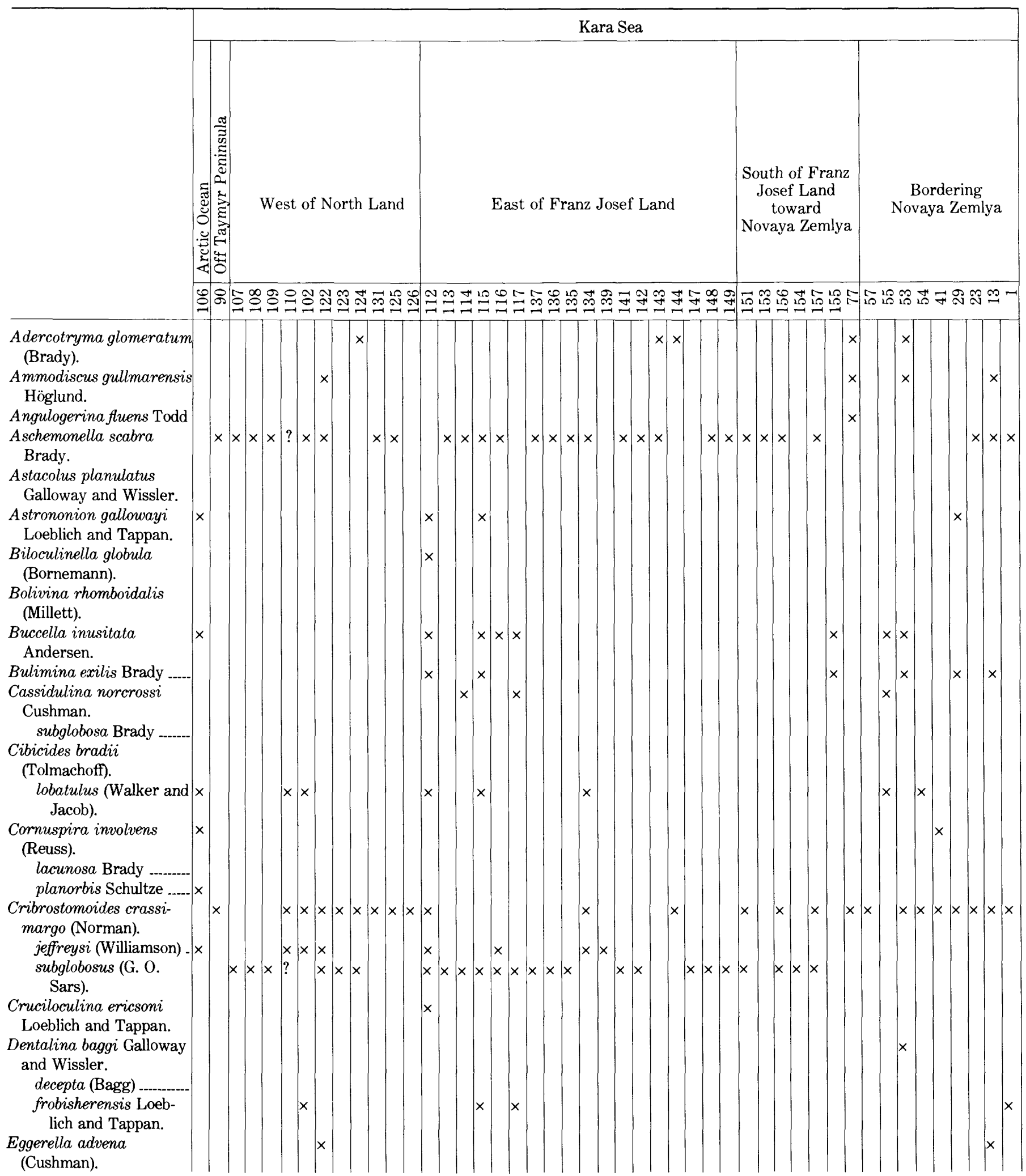


TABLE 1.-Distribution of species in the Kara and Greenland Seas-Continued

|

Adercotryma glomeratum
(Brady).
Ammodiscus gullmarensis
Höglund.

Angulogerina fuens Todd Aschemonella scabra

Brady.

Astacolus planulatus Galloway and Wissler.

Astrononion gallowayi

Loeblich and Tappan.

Biloculinella globula

(Bornemann).

Bolivina rhomboidalis

(Millett).

Buccella inusitata

Andersen.

Bulimina exilis Brady

Cassidulina norcrossi

Cushman.

subglobosa Brady

Cibicides bradii (Tolmachoff) -lobatulus (Walker and

Jacob).

Cornuspira involvens (Reuss) lacunosa Brady planorbis Schultze

Cribrostomoides crassimargo (Norman).

jeffreysi (Williamson) subglobosus (G. O. Sars)

Cruciloculina ericsoni

Loeblich and Tappan.

Dentalina baggi Galloway and

Wissler.

decepta (Bagg) .

frobisherensis Loeblich and

Tappan.

Eggerella advena (Cushman)

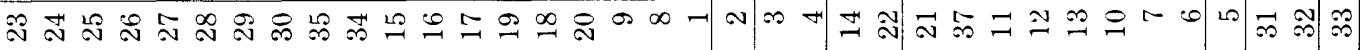

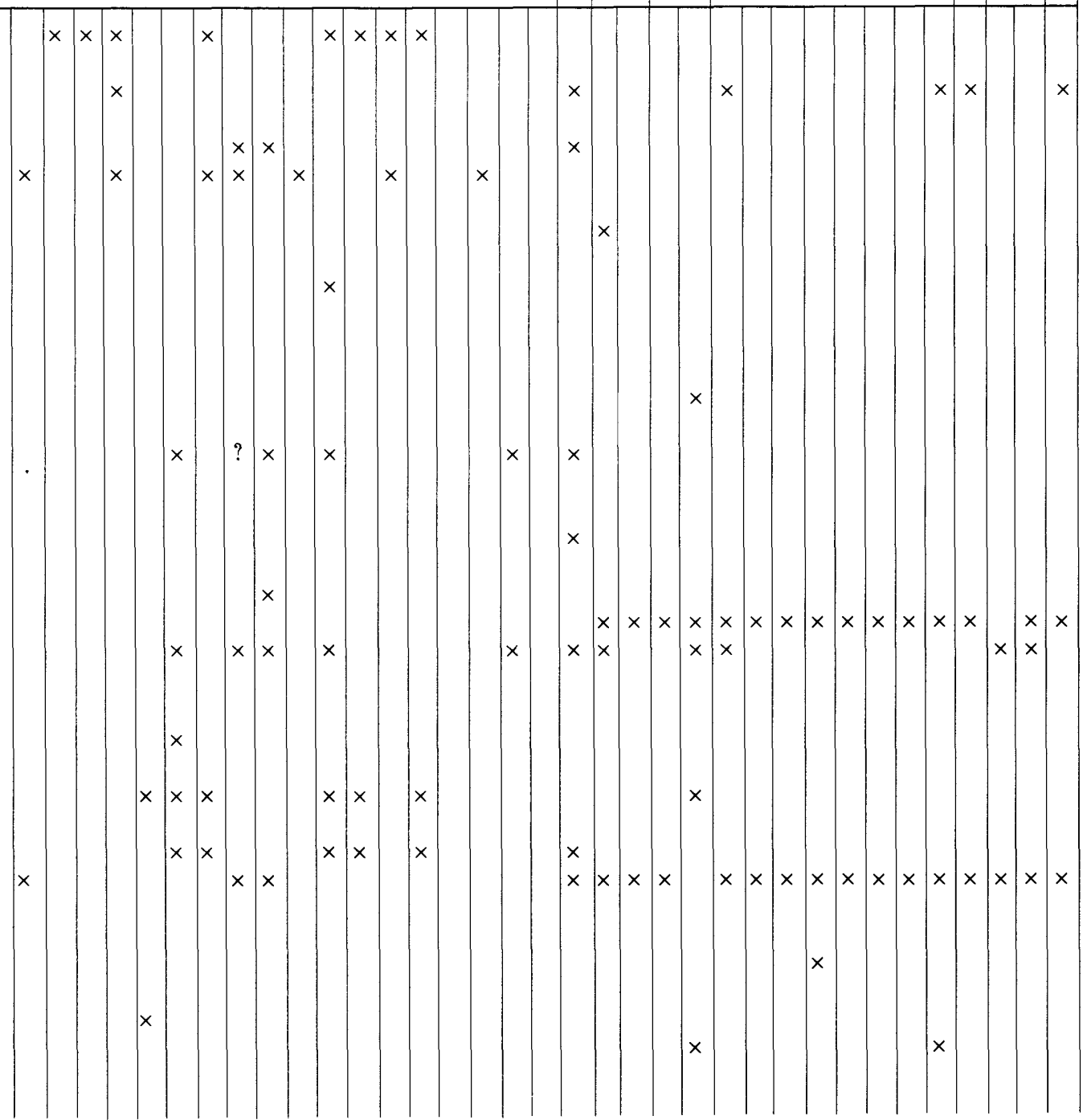


TABLE 1.-Distribution of species in the Kara and Greenland Seas-Continued

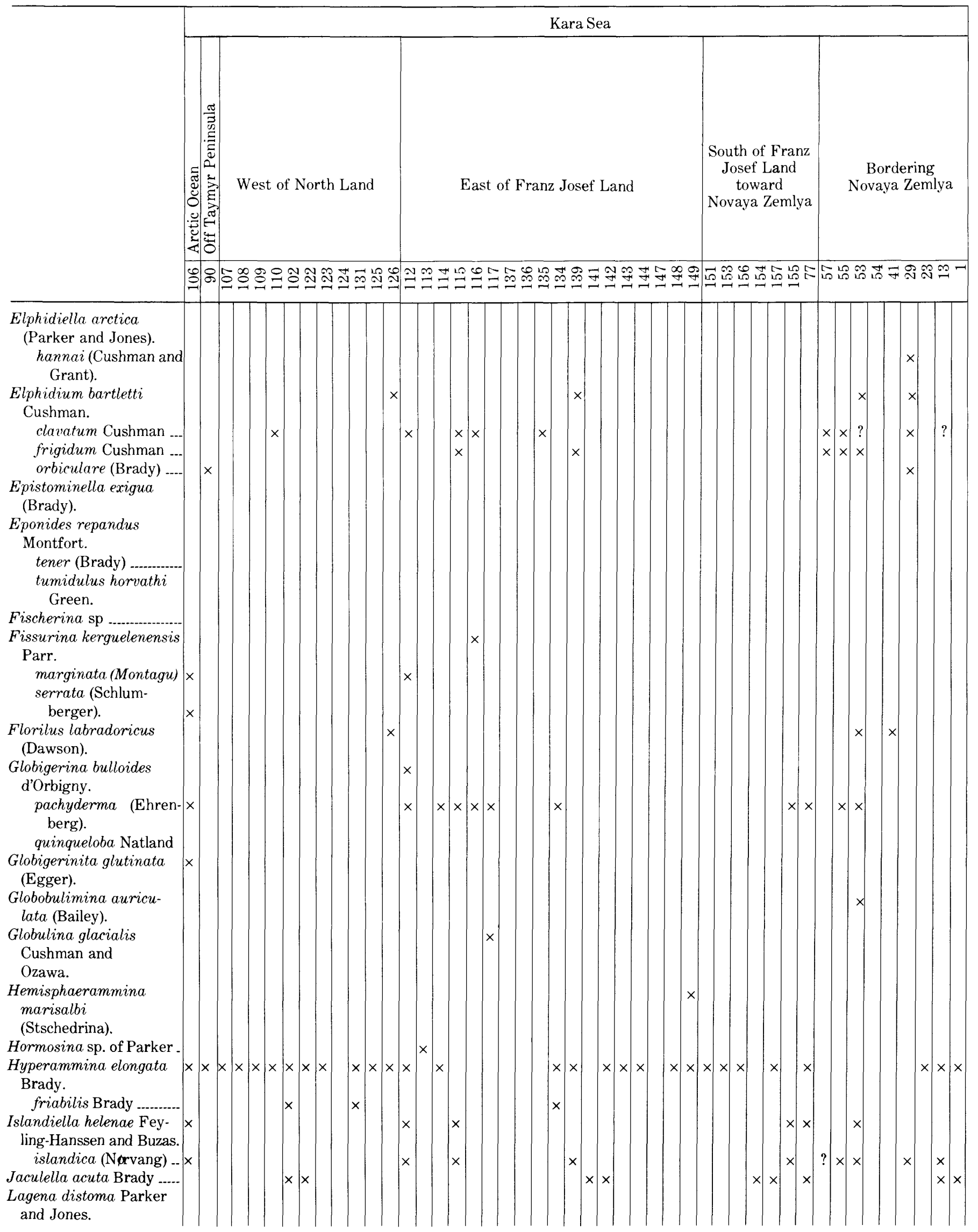


TABLE 1.-Distribution of species in the Kara and Greenland Seas-Continued

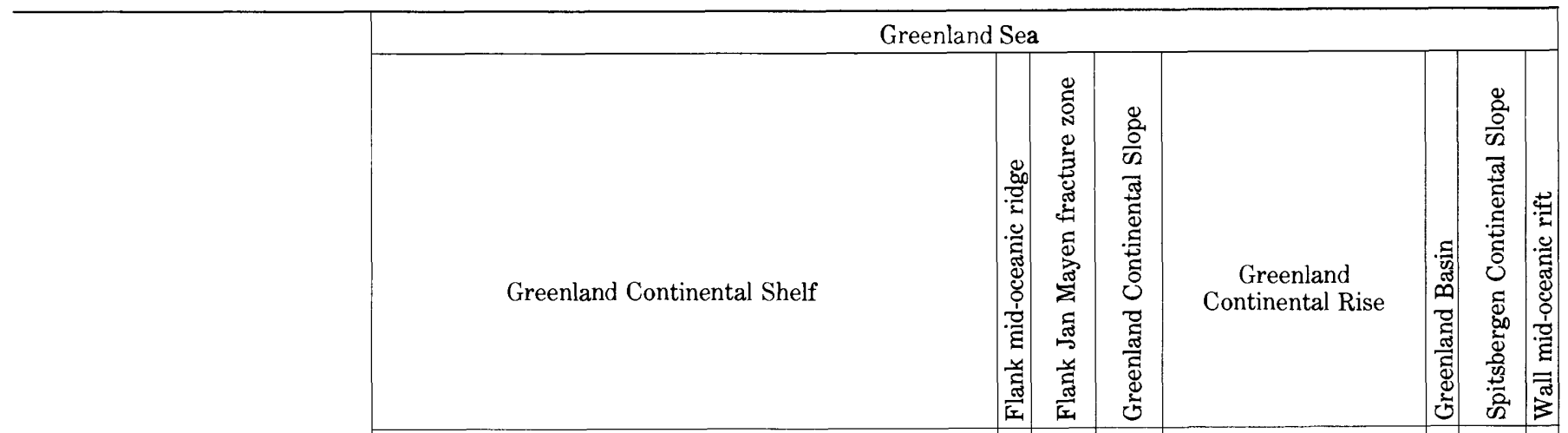

ఇ

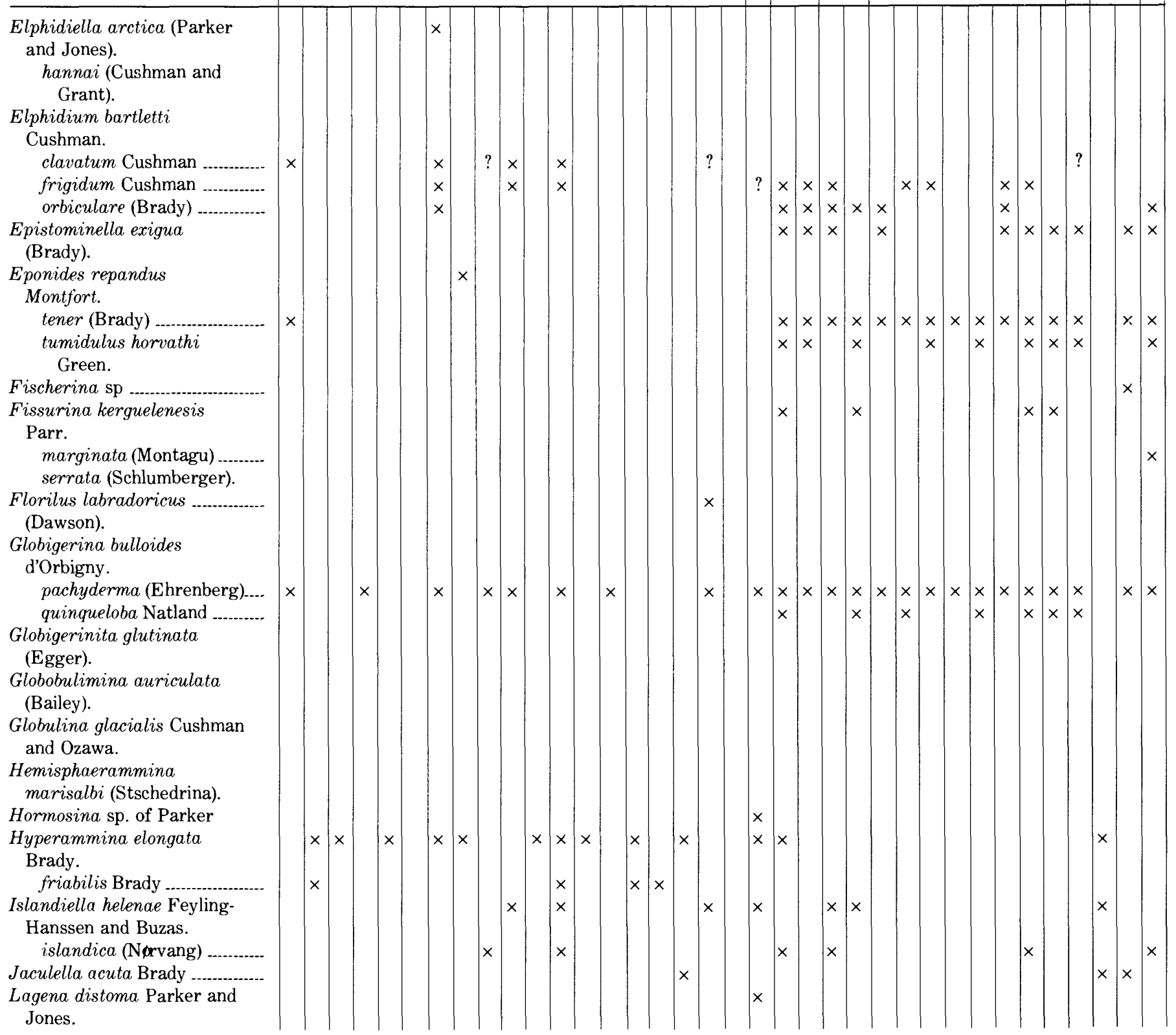


TABLE 1.-Distribution of species in the Kara and Greenland Seas-Continued

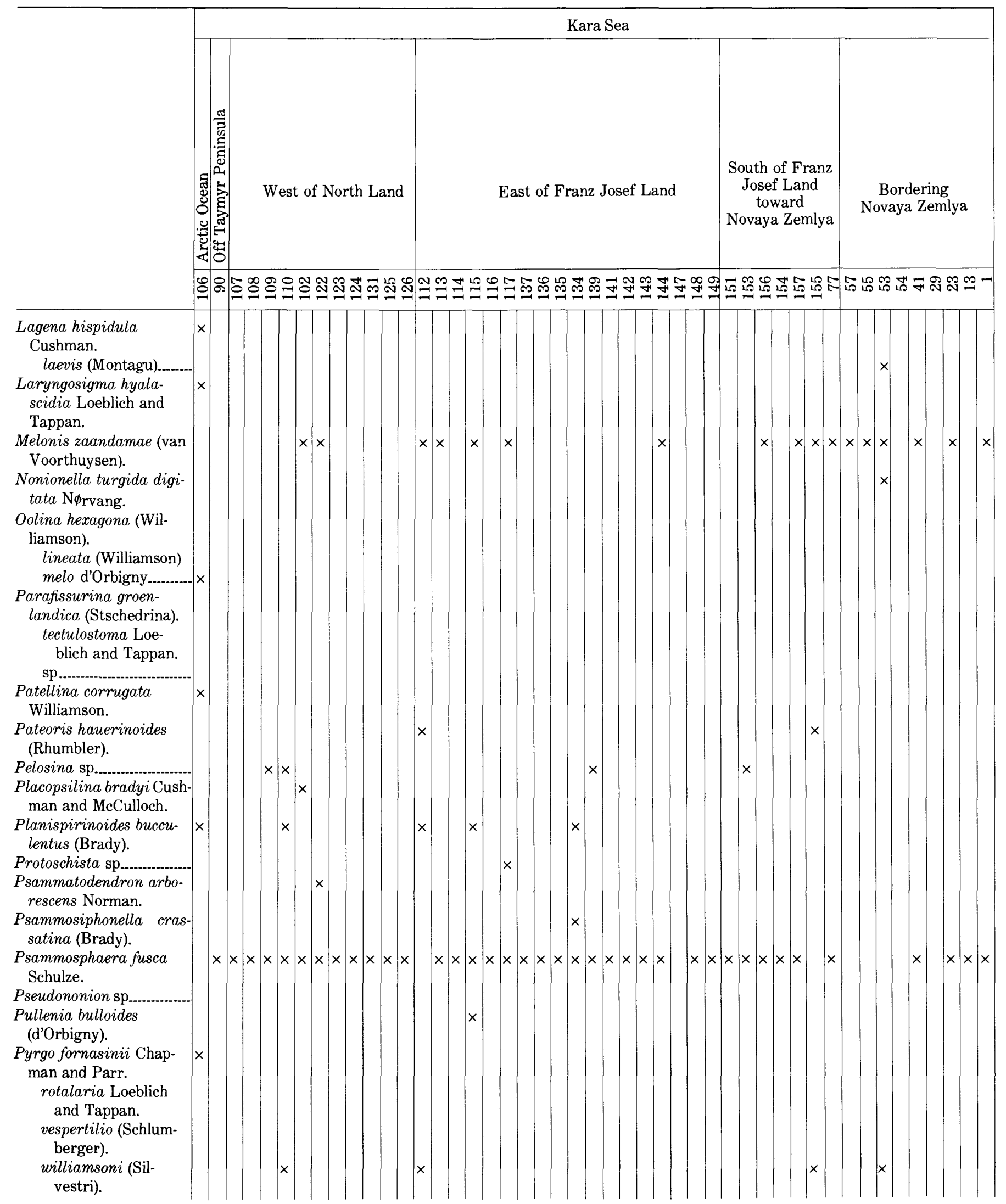


TABLE 1.-Distribution of species in the Kara and Greenland Seas - Continued.

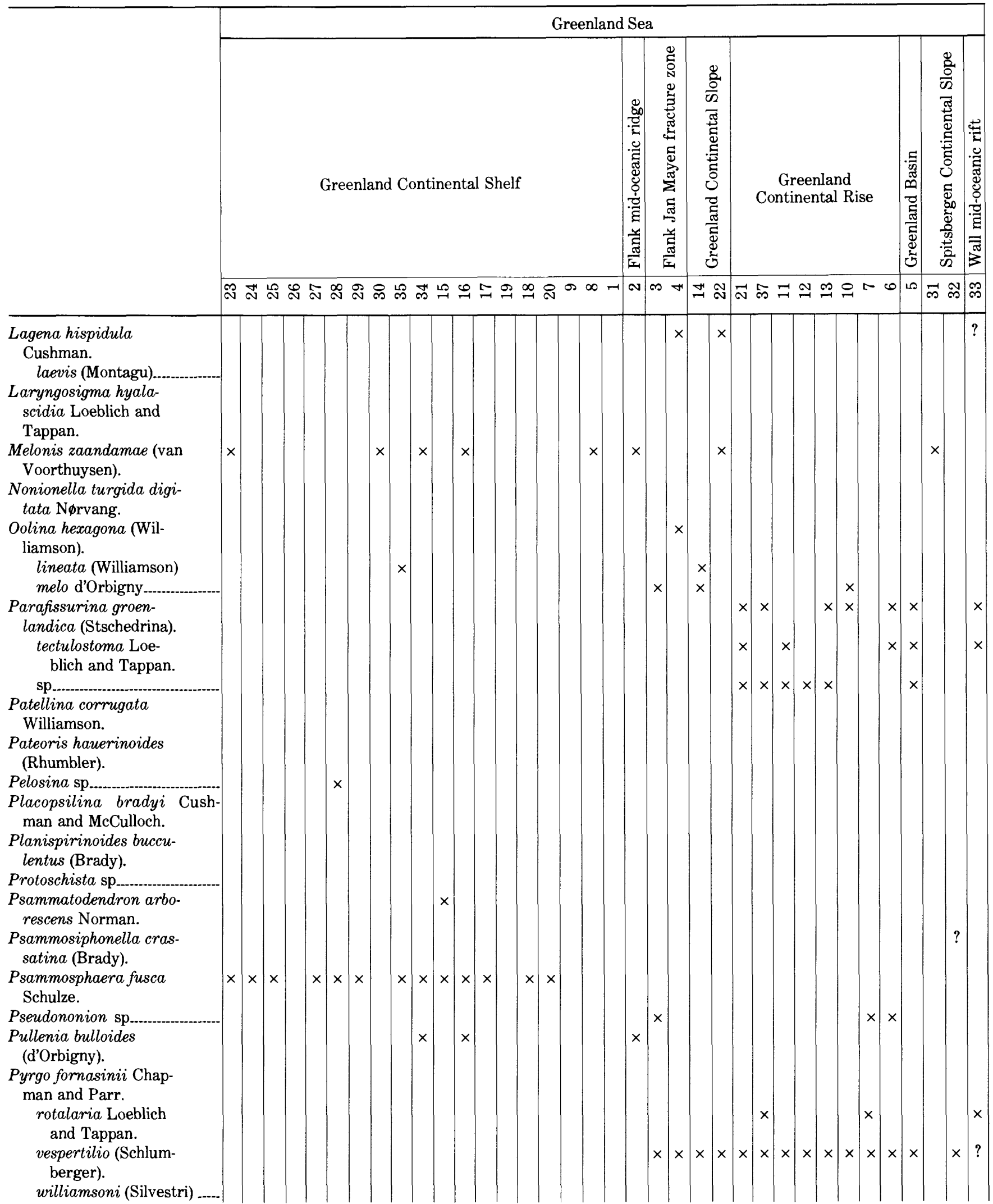


TABLE 1.-Distribution of species in the Kara and Greenland Seas-Continued

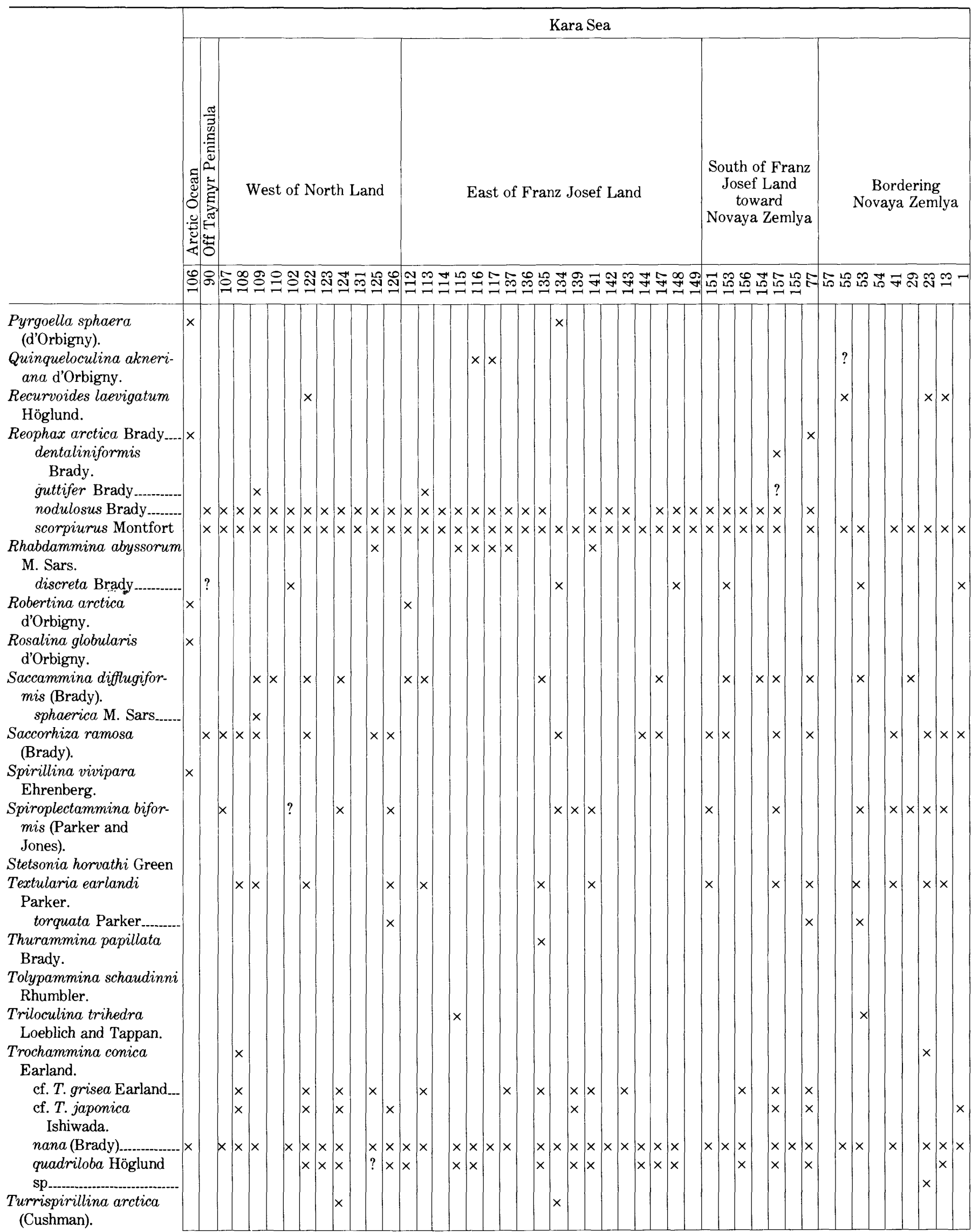


TABLE 1.-Distribution of species in the Kara and Greenland Seas-Continued

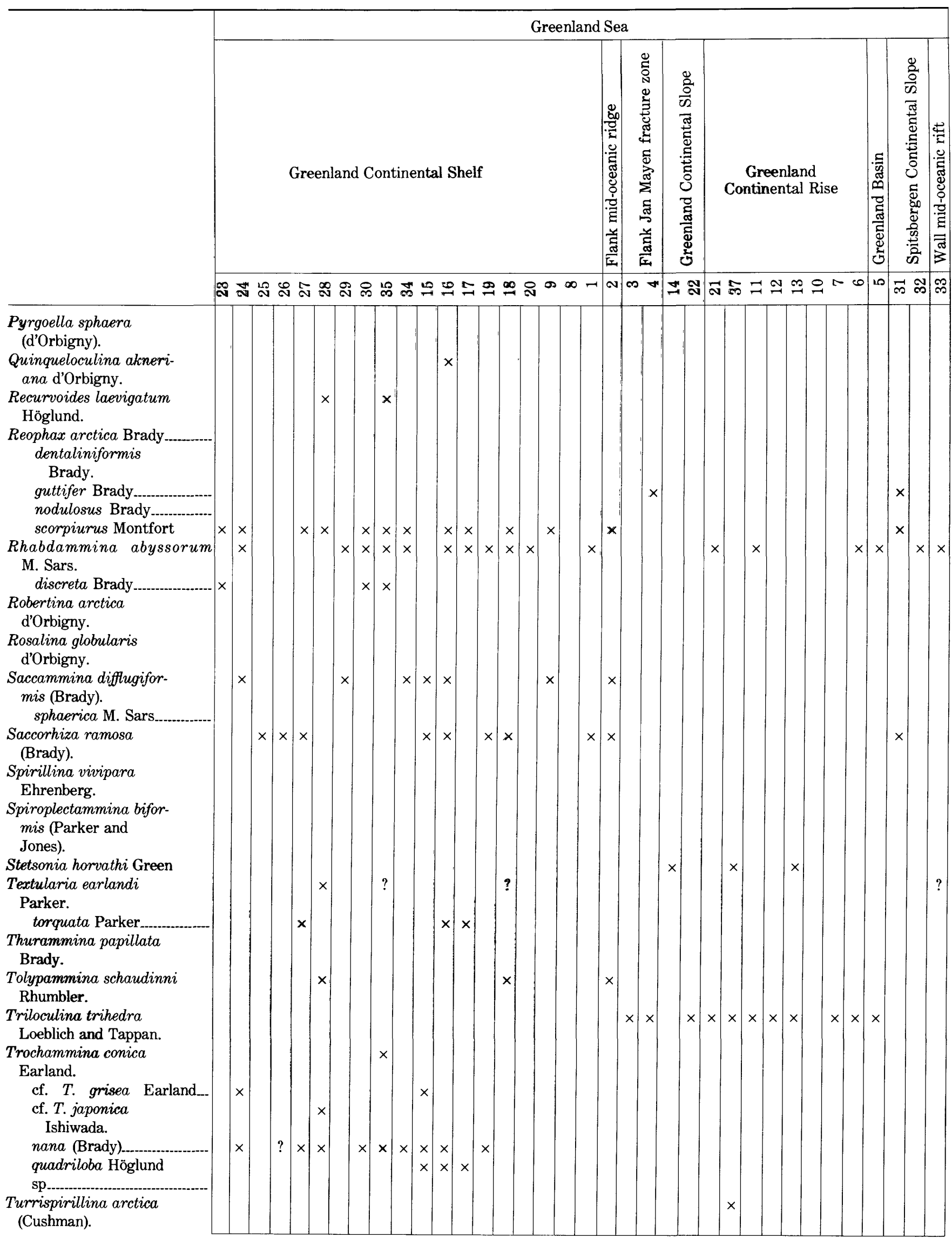


nental Shelf came from depths between 45 and 194 fathoms (about 82 and $355 \mathrm{~m}$ ). Those taken on continental slopes, basins, and rises came mostly from depths between 1,200 and 1,825 fathoms (about 2,195 and $3,340 \mathrm{~m}$ ).

On table 1 we have grouped the samples from Greenland Sea as follows :

Greenland Continental Shelf (19 samples ranging in depth from 45 to 194 fathoms [approx 82 and $355 \mathrm{~m}]$ )

Flank of mid-oceanic ridge (1 sample at 360 fathoms [approx $660 \mathrm{~m}$ ])

Flank of Jan Mayen fracture zone (2 samples, at 1,225 and 1,230 fathoms [approx 2,240 and $2,250 \mathrm{~m}]$ )

Greenland Continental Slope (2 samples, at 900 and 1,060 fathoms [approx 1,645 and 1,940 m])

Greenland Continental Rise (8 samples ranging in depth from 1,200 to 1,825 fathoms [approx $2,195$ and $3,340 \mathrm{~m}]$ )

Greenland Basin (1 sample at 1,560 fathoms [approx $2,855 \mathrm{~m}]$ )

Spitsbergen Continental Slope (2 samples, at 640 and 1,380 fathoms [approx 1,170 and 2,525 m])

Wall of mid-oceanic rift ( 1 sample at 1,750 fathoms [approx 3,200 m])

Samples from the Continental Shelf off northeastern Greenland, between approximately lat $71^{\circ}$ and $78^{\circ}$ N., contain faunas similar to, although sparser than, those from the Continental Shelf areas of the Kara Sea.

Kara and Greenland Seas Continental Shelf faunas are comparable except for Reophax nodulosus, which was not found on the Greenland Sea shelf. The three species found most often in the Kara Sea were likewise found most often on the Continental Shelf of the Greenland Sea-namely Psammosphaera fusca, Reophax scorpiurus, and Trochammina nana.

Comparatively deep areas of the Greenland Sea are inhabited by a distinctly different fauna from that observed at shelf depth. This change is due in part to the disappearance or the decrease of some of the Continental Shelf species, such as Hyperammina elongata, Psammosphaera fusca, Saccorhiza ramosa, Reophax scorpiurus, Rhabdammina abyssorum, and Trochammina nana and to the increase in abundance (that is, percentage at individual stations) of others, such as Cribrostomoides subglobosus and Globigerina pachyderma, plus other planktonic species.

In addition, this distinction is enhanced by the addition of the following deep-water species:
Cibicides bradii

Epistominella exigua

Eponides tener

E. tumidulus horvathi

Fissurina kerguelenensis

Parafissurina groenlandica

P. tectulostoma

$P$. sp.

Pyrgo vespertilio

Triloculina trihedra

Stetsonia horvathi

Finally, three deep-water samples collected west of Spitsbergen are generally similar to those from the deep-water samples of the Greenland Sea.

Acknowledgments.-We are grateful to the U.S. Naval Oceanographic Office for the opportunity of studying these samples. Many colleagues contributed advice and criticism in the course of our work, in particular, David L. Clark of the University of Wisconsin, C. Wylie Poag of the U.S. Geological Survey, and Charles T. Schafer of the Bedford Institute of Oceanography. Robert H. McKinney photographed the larger specimens. The smaller ones were photographed by Ruth Todd, and all illustrations were retouched by Doris Low.

\section{PREVIOUS STUDIES IN THE AREA}

Foraminifera have been studied from isolated areas in the Arctic regions for nearly 100 years. In an early assessment of foraminiferal faunas of the Arctic, Brady wrote, "The facts $* * *$ appear to indicate that there is no very striking diminution in the number and variety of the Rhizopoda as we approach the North Pole" (Brady, 1878, p. 439). Three years later, in describing and listing the faunas from 6 samples from the west side of Novaya Zemlya and 10 samples from the shores of Franz Josef Land, he reported a total of 71 species (Brady, 1881). In the six samples from the west side of Novaya Zemlya, at depths between 100 and $400 \mathrm{~m}$, a total of 54 species was reported, but no more than 32 species were observed in a single sample. In the 10 samples from around Franz Josef Land, taken at depths between 163 and $265 \mathrm{~m}$, the combined fauna consisted of 51 species, and the richest sample there had 30 species. The assemblages reported by Brady contained many species as well as combinations of species identical with those found in the present suite of samples. One of his samples (sample $\mathrm{G}$ from $230 \mathrm{~m}$, off Franz Josef Land) consisted almost entirely of specimens of Saccammina sphaerica. This feature is also characteristic of several of our Kara Sea samples. In these samples, however, the abundant form is Psam- 
TABLE 2.-Locality and depth of bottom-sediment samples from the Kara Sea, July 25-September 29, 1965

\begin{tabular}{|c|c|c|c|}
\hline & $\begin{array}{c}\text { Station } \\
\text { No. }\end{array}$ & Longitude & $\begin{array}{c}\text { Depth } \\
\text { (meters) }\end{array}$ \\
\hline 1 & $72^{\circ} 11.0^{\prime} \mathrm{N}$ & $57^{\circ} 10^{\prime} \mathrm{E}$. & 499 \\
\hline 13 & $\ldots 3^{\circ} 44.7^{\prime}$ & $59^{\circ} 37^{\prime}$ & 315 \\
\hline 23 & $-\ldots-14^{\circ} 29.5^{\prime}$ & $62^{\circ} 06^{\prime}$ & 320 \\
\hline 29 & $75^{\circ} 13.4^{\prime}$ & $68^{\circ} 34^{\prime}$ & 362 \\
\hline 41 & $75^{\circ} 50.1^{\prime}$ & $71^{\circ} 36^{\circ}$ & 223 \\
\hline 53 & $77^{\circ} 32.5^{\prime}$ & $71^{\circ} 36^{\prime}$ & 223 \\
\hline 54 & $76^{\circ} 44.5^{\prime}$ & $70^{\circ} 24^{\prime}$ & 443 \\
\hline 55 & $77^{\circ} 32.0^{\prime}$ & $67^{\circ} 00^{\prime}$ & 356 \\
\hline 57 & $77^{\circ} 31.0^{\prime}$ & $61^{\circ} 50^{\prime}$ & 265 \\
\hline 77 & $78^{\circ} 03.4^{\prime}$ & $74^{\circ} 39^{\prime}$ & 362 \\
\hline 90 & - $77^{\circ} 29.7^{\prime}$ & $98^{\circ} 37^{\prime}$ & 82 \\
\hline 102 & $81^{\circ} 04.1^{\prime}$ & $87^{\circ} 32^{\prime}$ & 340 \\
\hline 106 & $81^{\circ} 27.5^{\prime}$ & $97^{\circ} 34^{\prime}$ & 265 \\
\hline 107 & $81^{\circ} 30.5^{\prime}$ & $87^{\circ} 39^{\prime}$ & 420 \\
\hline 108 & $81^{\circ} 30.5^{\prime}$ & $84^{\circ} 54^{\prime}$ & 410 \\
\hline 109 & $81^{\circ} 30.6^{\prime}$ & $82^{\circ} 15^{\prime}$ & 423 \\
\hline 110 & $81^{\circ} 34.8^{\prime}$ & $79^{\circ} 52^{\prime}$ & 203 \\
\hline 112 & $81^{\circ} 37.0^{\prime}$ & $75^{\circ} 20^{\prime}$ & 421 \\
\hline 113 & $81^{\circ} 36.0^{\prime}$ & $73^{\circ} 00^{\prime}$ & 640 \\
\hline 114 & $81^{\circ} 42.3^{\prime}$ & $70^{\circ} 46^{\prime}$ & 631 \\
\hline 115 & $81^{\circ} 35.5^{\prime}$ & $67^{\circ} 32^{\prime}$ & 567 \\
\hline 116 & $81^{\circ} 02.2^{\prime}$ & $67^{\circ} 08^{\prime}$ & 475 \\
\hline 117 & $80^{\circ} 58.1^{\prime}$ & $69^{\circ} 34^{\prime}$ & 566 \\
\hline 122 & $81^{\circ} 08.0^{\prime}$ & $82^{\circ} 05^{\prime}$ & 268 \\
\hline 123 & $81^{\circ} 07.0^{\prime}$ & $83^{\circ} 58^{\prime}$ & 298 \\
\hline 124 & $80^{\circ} 35.8^{\prime}$ & $83^{\circ} 59^{\prime}$ & 315 \\
\hline 125 & $-\ldots 0^{\circ} 00.5^{\prime}$ & $84^{\circ} 01^{\prime}$ & 204 \\
\hline 126 & $79^{\circ} 35.5^{\prime}$ & $84^{\circ} 02^{\prime}$ & 217 \\
\hline 131 & $\ldots 0^{\circ} 41.1^{\prime}$ & $82^{\circ} 13^{\prime}$ & 202 \\
\hline 134 & $80^{\circ} 36.8^{\prime}$ & $74^{\circ} 32^{\prime}$ & 243 \\
\hline 135 & $-\ldots 0^{\circ} 39.9^{\prime}$ & $71^{\circ} 43^{\prime}$ & 593 \\
\hline 136 & $80^{\circ} 42.9^{\prime}$ & $69^{\circ} 10^{\prime}$ & 549 \\
\hline 137 & $80^{\circ} 45.1^{\prime}$ & $66^{\circ} 48^{\prime}$ & 498 \\
\hline 139 & $80^{\circ} 00.0^{\prime}$ & $64^{\circ} 15^{\prime}$ & 228 \\
\hline 141 & $80^{\circ} 00.0^{\prime}$ & $66^{\circ} 55^{\prime}$ & 520 \\
\hline 142 & $80^{\circ} 00.0^{\prime}$ & $69^{\circ} 47^{\prime}$ & 564 \\
\hline 143 & $80^{\circ} 00.0^{\prime}$ & $72^{\circ} 11^{\prime}$ & 538 \\
\hline 144 & $-\ldots 0^{\circ} 00.0^{\prime}$ & $74^{\circ} 36^{\prime}$ & 215 \\
\hline 147 & $79^{\circ} 34.9^{\prime}$ & $72^{\circ} 00^{\prime}$ & 521 \\
\hline 148 & $79^{\circ} 35.0^{\prime}$ & $69^{\circ} 27^{\prime}$ & 532 \\
\hline 149 & $79^{\circ} 35.2^{\prime}$ & $66^{\circ} 57^{\prime}$ & 526 \\
\hline 151 & $-79^{\circ} 06.2^{\prime}$ & $64^{\circ} 06^{\prime}$ & 260 \\
\hline 153 & $79^{\circ} 05.0^{\prime}$ & $74^{\circ} 09^{\prime}$ & 366 \\
\hline 154 & $78^{\circ} 37.3^{\prime}$ & $71^{\circ} 41^{\prime}$ & 485 \\
\hline 155 & $78^{\circ} 12.6^{\prime}$ & $69^{\circ} 00^{\prime}$ & 443 \\
\hline 156 & $78^{\circ} 50.7^{\prime}$ & $66^{\circ} 39^{\prime}$ & 374 \\
\hline 157 & $-78^{\circ} 33.0^{\prime}$ & $63^{\circ} 38^{\prime}$ & 346 \\
\hline
\end{tabular}

mosphaera fusca, a species superficially similar to Saccammina sphaerica.

Shortly following Brady's work, Goës prepared an illustrated catalog of the Arctic and Scandinavian species known at that time (Goës, 1894) and included with his synopsis a chronological summary of the various cruises and dredging excursions that had been carried out in the Arctic seas until that time. He pointed out that, even in spite of the various localities that had been searched, many new forms remained to be discovered.

For a report on the Norwegian-North Atlantic Expedition of 1876-78, Kiaer examined more than 100 samples, among which were 12 bottom samples from around Spitsbergen and 4 from near Jan Mayen Is-
TABLE 3.-Locality and depth of bottom-sediment samples from the Greenland Sea, August 23-September 12, 1965

\begin{tabular}{|c|c|c|c|c|c|}
\hline & $\begin{array}{c}\text { Sample } \\
\text { No. }\end{array}$ & $\begin{array}{l}\text { Lati- } \\
\text { tude }\end{array}$ & $\begin{array}{l}\text { Longi- } \\
\text { tude }\end{array}$ & $\begin{array}{l}\text { Approx. } \\
\text { depth } \\
\text { (meters) }\end{array}$ & $\begin{array}{c}\text { Depth } \\
\text { from log } \\
\text { (fathoms) }\end{array}$ \\
\hline 1 & - & $70^{\circ} 54.8^{\prime} \mathrm{N}$ & $20^{\circ} 29.7^{\prime} \mathrm{W}$ & 330 & 180 \\
\hline 2 & - - & $70^{\circ} 56.8^{\prime}$ & $12^{\circ} 51^{\prime}$ & 660 & 360 \\
\hline 3 & 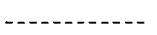 & $71^{\circ} 53^{\prime}$ & $12^{\circ} 14^{\prime}$ & 2,250 & 1,230 \\
\hline 4 & 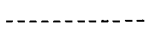 & $72^{\circ} 21^{\prime}$ & $11^{\circ} 56^{\prime}$ & 2,240 & 1,225 \\
\hline 5 & $--1-1-1-1$ & $73^{\circ} 14.2^{\prime}$ & $11^{\circ} 42.5^{\prime}$ & 2,855 & 1,560 \\
\hline 6 & - & $73^{\circ} 16.5^{\prime}$ & $12^{\circ} 30.5^{\prime}$ & 2,655 & 1,450 \\
\hline 7 & - - - & $73^{\circ} 14^{\prime}$ & $13^{\circ} 30^{\prime}$ & 2,545 & 1,392 \\
\hline 8 & - & $73^{\circ} 23^{\prime}$ & $18^{\circ} 03^{\prime}$ & 230 & 125 \\
\hline 9 & 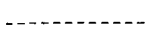 & $73^{\circ} 25.3^{\prime}$ & $17^{\circ} 03^{\prime}$ & 330 & 181 \\
\hline 10 & - - & $73^{\circ} 26.5^{\prime}$ & $15^{\circ} 22^{\prime}$ & 2,195 & 1,200 \\
\hline 11 & - - - & $74^{\circ} 15^{\prime}$ & $07^{\circ} 03^{\prime}$ & 3,340 & 1,825 \\
\hline 12 & - - & $74^{\circ} 30^{\prime}$ & $08^{\circ} 55^{\prime}$ & 3,295 & 1,800 \\
\hline 13 & - & $74^{\circ} 48^{\prime}$ & $10^{\circ} 34^{\prime}$ & 3,110 & 1,700 \\
\hline 14 & - & $75^{\circ} 17^{\prime}$ & $11^{\circ} 22^{\prime}$ & 1,940 & 1,060 \\
\hline 15 & 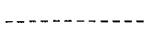 & $75^{\circ} 35^{\prime}$ & $12^{\circ} 50^{\prime}$ & 230 & 126 \\
\hline 16 & $--1-1-1$, & $75^{\circ} 43^{\prime}$ & $13^{\circ} 27^{\prime}$ & 240 & 132 \\
\hline 17 & $-\ldots+n-1,-n$ & $75^{\circ} 51^{\prime}$ & $14^{\circ} 21^{\prime}$ & 260 & 142 \\
\hline 18 & - - & $75^{\circ} 48^{\prime}$ & $15^{\circ} 16^{\prime}$ & 240 & 131 \\
\hline 19 & - & $75^{\circ} 52^{\prime}$ & $15^{\circ} 17^{\prime}$ & 165 & 90 \\
\hline 20 & - - - & $75^{\circ} 43.8^{\prime}$ & $15^{\circ} 56^{\prime}$ & 165 & 90 \\
\hline 21 & - & $78^{\circ} 20.2^{\prime}$ & $00^{\circ} 42.5^{\prime}$ & 2,965 & 1,620 \\
\hline 22 & - & $78^{\circ} 20.5^{\prime}$ & $04^{\circ} 12^{\prime}$ & 1,645 & 900 \\
\hline 23 & - - - & $78^{\circ} 18.5^{\prime}$ & $05^{\circ} 40^{\prime}$ & 355 & 194 \\
\hline 24 & - & $78^{\circ} 18.5^{\prime}$ & $06^{\circ} 53^{\prime}$ & 265 & 145 \\
\hline 25 & $--1-1, \ldots$ & $78^{\circ} 20^{\prime}$ & $08^{\circ} 13^{\prime}$ & 196 & 107 \\
\hline 26 & 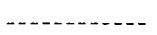 & $78^{\circ} 22^{\prime}$ & $09^{\circ} 15^{\prime}$ & 248 & 135 \\
\hline 27 & - - & $78^{\circ} 21^{\prime}$ & $10^{\circ} 43^{\prime}$ & 205 & 112 \\
\hline 28 & $----1-1-1$ & $78^{\circ} 19^{\prime}$ & $11^{\circ} 56^{\prime}$ & 152 & 83 \\
\hline 29 & - - + - & $78^{\circ} 20^{\prime}$ & $13^{\circ} 40^{\prime}$ & 132 & 72 \\
\hline 30 & - & $78^{\circ} 21.5^{\prime}$ & $14^{\circ} 26^{\prime}$ & 82 & 45 \\
\hline 31 & 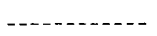 & $80^{\circ} 00^{\prime}$ & $04^{\circ} 15^{\prime} \mathrm{E}$. & 1,170 & 640 \\
\hline 32 & - - - & $80^{\circ} 00^{\prime}$ & $03^{\circ} 03^{\prime}$ & 2,525 & 1,380 \\
\hline 33 & - & $80^{\circ} 01^{\prime}$ & $01^{\circ} 07.5^{\prime}$ & 3,200 & 1,750 \\
\hline 34 & - - & $76^{\circ} 57.5^{\prime}$ & $08^{\circ} 01^{\prime} \mathrm{W}$. & 308 & 168 \\
\hline 35 & - & $76^{\circ} 51^{\prime}$ & $07^{\circ} 10^{\prime}$ & 322 & 176 \\
\hline 37 & - & $76^{\circ} 10.6^{\prime}$ & $05^{\circ} 04^{\prime}$ & 2,930 & 1,600 \\
\hline
\end{tabular}

land (Kiaer, 1899). From the composite of his 12 Spitsbergen samples, Kiaer reported 42 species, and from the 4 Jan Mayen samples, he found 39 species. His quantitative list of $\mathbf{1 6 6}$ species is typical of what is now known of the Arctic population; that is, sparse, erratic, and with a tendency toward strong dominance of certain species. He mentioned such dominating species as Saccammina sphaerica, Rhabdammina abyssorum, and Truncatulina [=Cibicides] lobatulus. Many of Kiaer's species are undoubtedly identical with our species, though some appear under different generic names and a few under different specific names.

Awerinzew (1911) reported the Foraminifera found in two samples from rather shallow water from the southern and eastern parts of the Kara Sea. His samples 2 and 3 from 37 and $38 \mathrm{~m}$ respectively are taken from much shallower water than any of our Kara Sea samples. Both his samples contained meager faunas, six and nine species respectively. Although reported under different generic or specific 
names, the following species probably appear in both Awerinzew's and our assemblages :

\begin{tabular}{|c|c|}
\hline Species of Awerinzew (1911) & Species of this paper \\
\hline Reophax scorpiurus Montfort & Reophax scorpiurus Montfort. \\
\hline Haplophragmium nanum Brady ... & Trochammina nana (Brady). \\
\hline Nonionina scapha Fichtel and Moll_ & Florilus labradoricus (Dawson). \\
\hline Nonionina stelligera d'Orbigny _..- & $\begin{array}{l}\text { Astrononion gallowayi Loeblich and } \\
\text { Tappan. }\end{array}$ \\
\hline \multicolumn{2}{|l|}{ Haplophragmium canariense } \\
\hline d'Orbigny - & $\begin{array}{l}\text { Cribrostomoides jeffreysi } \\
\text { (Williamson). }\end{array}$ \\
\hline $\begin{array}{l}\text { Polystomella striatopunctata } \\
\text { Fichtel and Moll var. incerta } \\
\text { Williamson. }\end{array}$ & Elphidium clavatum Cushman. \\
\hline Cassidulina laevigata d'Orbigny _.-- & $\begin{array}{l}\text { Islandiella helenae Feyling-Hanssen } \\
\text { and Buzas. }\end{array}$ \\
\hline Hyperammina arborescens Norman & $\begin{array}{l}\text { Psammatodendron arborescens } \\
\text { Norman. }\end{array}$ \\
\hline Trochammina nitida Brady .... & Trochammina cf. T. grisea Earland. \\
\hline
\end{tabular}

Stschedrina, in a number of papers, reported on the distribution of species in the Kara Sea (1936, 1938, 1958), Greenland Sea (1947, 1964a), and Arctic Basin (1964b).

In a pioneer study of the Kara Sea foraminiferal fauna, Stschedrina (1936) summarized the results of analysis of the rich collections made during the years from 1929 to 1936 by two Russian expeditions into the region. She presented an annotated listing of 43 species found in the Polar Seas and included quantitative tables, in broad terms, showing their occurrences around North Land (nine samples between 24 and $52 \mathrm{~m}$ ) ; in the southeastern Kara Sea between Sverdrup Island and Dickson (six samples between 17 and $28 \mathrm{~m}$ ) ; Shokalsky Strait, within the island group called North Land (six samples between 43 and $276 \mathrm{~m}$ ) ; at Cape Cheluskina, the northernmost point of Taymyr Peninsula (two samples at $47 \mathrm{~m})$; and Vilkitsky Strait between Cape Cheluskina and North Land (eight samples between 100 and $206 \mathrm{~m}$ ).

As is true of our present samples, most of these Kara samples had few species; those bordering North Land and from shallow depths around Sverdrup Island and Dickson averaged only slightly more than two species per sample. The richest samples were found in the two straits, but even there the assemblages were not very diverse, the maximum number of species per sample being 16 in Shokalsky Strait and 10 in Vilkitsky Strait. The dominating species were mostly agglutinated, with one exception; namely the richest sample from a shallow location in Shokalsky Strait, where Planispirina sphaera [Pyrgoella sphaera] and Cibicides sp. share dominance.

Besides cosmopolitan species, the following species recorded by Stschedrina (1936) seem to be identical with those we have observed, though sometimes under different names:

Hyperammina elongata Brady Rhabdammina abyssorum M. Sars

Hyperammina arborescens Norman

Reophax dentaliniformis Brady

$R$. scorpiurus Montfort

Triloculina bucculenta (Brady)

Planispirina sphaera d'Orbigny

Cornuspira involvens (Reuss)

Elphidium incertum (Williamson)

Cassidulina laevigata d'Orbigny

Cibicides lobatulus (Walker and Jacob)

In a summary report, Stschedrina (1938) judged that the Kara Sea foraminiferal fauna consisted of 102 species and divided her study area into eight regions, each characterized by certain species or groups of species from the three complexes of forms which compose the general population of the Kara Sea, namely: (1) species characteristic of shoal areas of cold seas, littoral zones and mouths of rivers, including species that can withstand considerable reduction of salinity; (2) cold-water arctic species widespread in the Kara Sea, including cosmopolitan species; and (3) boreal-arctic, boreal, and northern Atlantic species, as well as abyssal species from the Pacific and Atlantic Oceans, a group of species referred to as the "Atlantic complex."

In a preliminary summary of the foraminiferal fauna of the northern part of the Greenland Sea, Stschedrina (1947) recorded quantitatively the occurrence of 91 species at 11 stations ranging in depth from 225 to $3,000 \mathrm{~m}$. She recognized two complexes: (1) her previously described "Atlantic complex" of species, most of them abyssal, peculiar to the Greenland Sea and to certain other Arctic regions and (2) the "Arctic complex" of species, most of them eurybathyal and widespread all over the Arctic.

The samples upon which Stschedrina's analyses were made include some from depths shallower than any of our samples. Nevertheless, the fauna she reported is very similar to our listing herein. Most of the species in our assemblages are those typical of the "Atlantic" and "Arctic" complexes.

In 1958 Stschedrina reported on a core of $97.8 \mathrm{~cm}$ of sediment obtained from the Kara Sea, the lower two-thirds of which contained Late Cretaceous and Paleocene Foraminifera. In the upper one-third of the core a typical Arctic fauna provides evidence of a thin layer of modern sediment overlying the bedrock.

Two of her papers in 1964 list the faunas found in the northern part of the Greenland Sea (114 species) and in the Arctic Basin (162 species). 
In the Greenland Sea paper (Stschedrina, 1964a), the species are also recorded in separate check lists of agglutinated and calcareous species from around Spitsbergen, the Continental Shelf ( 5 samples from 130 to $225 \mathrm{~m}$ ) and the Continental Slope (6 samples from 659 to $1,825 \mathrm{~m}$ ) ; from the central part of the Greenland Sea (7 samples from 2,581 to $3,835 \mathrm{~m}$ ); and from off Greenland, the Continental Shelf (12 samples from 51 to $259 \mathrm{~m}$ ) and the Continental Slope (6 samples from 368 to $1,840 \mathrm{~m}$ ).

In her Arctic Basin paper, Stschedrina (1964b) divided the species into three ecologically significant groups: sublittoral, eulittoral, and abyssal-bathyal. The first two groups contain, respectively, 8 sparsely represented species and 27 well-represented species and constitute the "Arctic complex." The abyssalbathyal group of species includes 25 well-represented species of the "Atlantic complex."

She also plotted the occurrences of these 60 species in shelf and slope habitats around Spitsbergen and around Franz Josef Land and in lower flat and ocean-floor habitats of the central part of the Arctic Basin. Her "Arctic complex" of species is that mainly occupying the sublittoral and eulittoral zones, and the "Atlantic complex" of species is that mainly occupying the abyssal-bathyal zone. But in this grouping of species there is much overlap; that is, not all the sublittoral species, such as Spiroplectammina biformis and Pateoris hauerinoides, are unknown on the continental slopes. Nor are all the eulittoral species, such as Saccorhiza ramosa, unknown in both the shelf areas and the lower parts of the Arctic Ocean. Moreover, representatives of the abyssal-bathyal group of species are found at shallow depths as well as the deepest, but only four species are found exclusively on the floor of the Arctic Ocean.

Nearshore species of several coastal areas of Spitsbergen were well documented by Nagy (1963) and Rouvillois (1966) and illustrated in the former report. Nagy reported 60 species from 45 samples at depths between 0 and $51 \mathrm{~m}$. Rouvillois found 32 species between depths of 0 and $25 \mathrm{~m}$. Distribution is erratic and patchy.

Among species dominating in various samples were Astrononion gallowayi, Buccella frigida, Cassidulina crassa, C. islandica, Cibicides lobatulus, Elphidium clavatum, Pateoris hauerinoides, Spiro.plectammina biformis, and Tholosina bulla.

Green (1960) discussed the ecology of Arctic Foraminifera and based his conclusions on cores of the central Arctic Ocean, taken between 433 and 2,760 $\mathrm{m}$. His total assemblage consisted of 105 species of which he found 20 to be useful in depth zonation. He recognized four depth zones-shelf, slope, apron, and abyssal-and listed a few species as diagnostic of each zone. Those we have in common with his central Arctic Ocean material are: Cassidulina teretis, C. islandica, Cibicides lobatulus, and Elphidium bartletti from the shelf; Trochammina nana and Cassidulina norcrossi from the slope; Eponides tumidulus horvathi and Triloculina trihedra from the apron; and Eponides tener, Quinqueloculina akneriana, Stetsonia horvathi, and Cibicides wuellerstorfi [our $C$. bradii] in the abyssal zone.

The above-mentioned species are not in all instances separable into the same depth zones. For example, Trochammina nana is found chiefly in our shelf fauna; Quinqueloculina akneriana is absent from our deeper samples and is present only sparsely in our shelf fauna; and Eponides tener and E. tumidulus horvathi are found together in our samples from the deepest water.

Because of its greater depth and its basinal rather than shelf origin, Green's fauna (1960) has only a small proportion of its elements in common with our assemblages.

Androsova (1962) reported quantitatively on the species present in a part of the Polar Basin, between the North Pole and northern Greenland and Spitsbergen. Seven short cores were studied, ranging in length from 4 to $20 \mathrm{~cm}$, taken at depths between 3,767 and $4,395 \mathrm{~m}$. The fauna is meager, consisting of 13 benthonic and 6 planktonic species, and the population is predominantly planktonic. Only five of the benthonic species are the same as those that we have from the deeper parts of the Greenland Sea.

Some bottom sediments from the Kara Sea and around Franz Josef Land, obtained by several Russian ships between 1953 and 1958, were quantitatively analyzed and their Foraminifera assemblages compared with those in some outcrops and well drillings in the northern part of western Siberia (Basov and Slobodin, 1965). Pie diagrams (Basov and Slobodin, 1965, text figs. 2-18) show graphically the abundance, diversity, species composition, and dominance for several areas. For the three sampled depths around Franz Josef Land, results were as follows :

Between 24 and $27 \mathrm{~m}$ Cibicides rotundatus Stschedrina [probably equivalent to our $C$. lobatulus] is dominant and is accompanied by several species of Elphidium in the sublittoral zone. These two groups together compose nearly three-quarters of the abundant fauna. A much less abundant but more varied fauna was sampled between 20 and $80 \mathrm{~m}$ in the Tikhaya and Yuri Bay areas where Spiroplectammina biformis and Haplophragmoides sp. are dominant 
and are accompanied by various other agglutinated forms as well as by a few specimens of Cibicides, Cassidulina, and Elphidium. In the upper bathyal zone around Franz Josef Land, a moderately abundant and diverse fauna sampled between 220 and 500 $\mathrm{m}$ is not strongly dominated by any species, but Adercotryma glomeratum, Haplophragmoides sp., Proteonina difflugiformis, and Spiroplectammina biformis combine to make up 59 percent of the assemblage. The balance consists mostly of other agglutinated forms and of species of Elphidium, Cassidulina, and Nonionellina [our Florilus].

In the northeastern part of the Kara Sea, bottom samples from 350,70 , and $40 \mathrm{~m}$ vary in abundance, but all show low diversity (seven, five, and eight species, respectively) but little uniformity. In the most northern sample, at $350 \mathrm{~m}$, four species in the family Elphidiidae make up more than half the population; the balance is divided almost equally among species of Cassidulina [our Islandiella], Virgulina, Globulina, and Haplophragmoides. The sample from $70 \mathrm{~m}$ was moderately abundant in, and strongly dominated by, Eggerella advena (nearly 85 percent). In the sample from $40 \mathrm{~m}$, two species share dominance-Trochammina karica Stschedrina [our T. nana] and Globigerina pachyderma (Ehrenberg) together making up 78 percent of the total population.

Two bottom samples in the southwestern part of the Kara Sea at 90 and $63 \mathrm{~m}$ showed moderate diversity (12-14 species), but no strong dominances. In both samples, Elphidium clavatum was the most abundant species. The other chief components of the faunas were additional species of Elphidium plus species in the genera Cassidulina [our Islandiella] and Nonionellina [our Florilus].

In a sparse fauna represented by three bottom samples taken at depths of 23 to $40 \mathrm{~m}$ in the sublittoral area of the southeastern part of the Kara Sea, the assemblage was moderately dominated by $E l$ phidium orbiculare, and most of the remaining species fell under the genera Elphidium, Cassidulina, Trochammina, and Globigerina. This assemblage has developed in response to the outflowing of freshwater from the $\mathrm{Ob}$ ' and Yenisey Rivers.

The foraminiferal fauna of the Laptev Sea was sampled in 1963 and briefly recorded (Todd and Low, 1966). In the analysis of 33 bottom-sediment samples, ranging in depth from 10 to $54 \mathrm{~m}, 16$ arenaceous and 24 calcareous species were found. Most of the samples contained a sparse fauna of between 1 and 5 species. The two richest samples, one at 22 $\mathrm{m}$ and another at $53 \mathrm{~m}$, contained 18 and 19 species respectively.

The assemblage of 40 species represents Stschedrina's sublittoral group of species, which she described (1959) as characteristic of the Continental Shelf, subject to seasonal fluctuations that are related to a reduction in the salinity of bottom water. More than half the species are the same as those we have observed from the Kara Sea, but, of the dominating species in the Kara Sea, only three (Cribrostomoides crassimargo, Reophax scorpiurus, and Trochammina nana) are present in the Laptev Sea. In general, the Laptev fauna lacks the large robust forms that are typical of the deeper water of the Kara Sea.

Vilks (1969) studied the Foraminifera in the icecovered seas of the Canadian Arctic, between approximately lat $75^{\circ} 30^{\prime}$ and $77^{\circ} 30^{\prime} \mathrm{N}$. and long $109^{\circ}$ and $116^{\circ} \mathrm{W}$. In his quantitative analysis of samples taken between 17 and $458 \mathrm{~m}$, he found two bathymetric zones on the Continental Shelf. Their common boundary at about $200 \mathrm{~m}$ separated the upper zone of Arctic surface water, inhabited principally by arenaceous species, from the lower zone of warmer and more saline water of Atlantic origin, inhabited principally by calcareous species.

His combined assemblage of 78 species contained many species in common with our assemblages from the Kara and Greenland Seas but lacked, or had only rare representatives of, several of our larger and more robust arenaceous and porcellaneous species, such as Aschemonella scabra, Pelosina cylindrica, Planispirinoides bucculentus, Psammosphaera fusca, Pyrgo vespertilio, and Rhabdammina abyssorum.

In a report on the Barents Sea, Digas (1971) studied the foraminiferal fauna of a small area in the central part of the sea. The study included 17 stations located between about lat $74^{\circ}$ and $76^{\circ} \mathrm{N}$. and long $30^{\circ}$ and $411 / 2^{\circ}$ E., at depths between 153 and $335 \mathrm{~m}$. Fifty-four calcareous species and 25 arenaceous ones are recorded, the arenaceous species being more abundant. The richest samples contain from 35 to 42 species ( 25 to 30 calcareous species and 10 to 12 arenaceous ones). Each of the samples is strongly dominated by one or several species, mostly by arenaceous species. One sample (No. 19) consisted of 70 percent Adercotryma glomeratum. Conversely, one of the rich samples (No. 7) contains conspicuously fewer arenaceous species and specimens-21 calcareous and 11 arenaceous species-and the dominance is shared among Buccella frigida, Quinqueloculina sp., and Cibicides sp. 
In general, this Barents Sea fauna contains many species in common with the Kara and Greenland Sea faunas of comparable depths and, like them, is highly variable from station to station.

Slobodin and Tamanova (1972, tables $2-7$ on p. 25-30) made quantitative studies of the foraminiferal assemblages in six Kara Sea cores ranging in length from 2.44 to $5.37 \mathrm{~m}$. Four of these cores were from east of the southern end of Novaya Zemlya at depths between 108 and $372 \mathrm{~m}$, and two were from the northern part of the Kara Sea between North Land and Franz Josef Land at 304 and $482 \mathrm{~m}$ (Slobodin and Tamanova, 1972, map on p. 31). Hence, these cores may be compared to our present samples. Analyses of these cores show rich assemblages in the top sample of each core, with but one exception, and these quantitative records give a fairly detailed picture of the bottom fauna characteristic of this part of the Kara Sea, covering a distance of about 1,200 $\mathrm{km}$. From these cores we can see the predominance of agglutinated forms, elphidiids, and cassidulinids, and the widespread dominance of Trochammina karica Stschedrina [our T. nana]. This species has a strong position of dominance in two of the cores, shares dominance with another species in two more of the cores, and is present but rare in the other two cores.

Other species well represented in this part of the Kara Sea, as reported by Slobodin and Tamanova (1972) and present in our samples though some less abundantly, are:

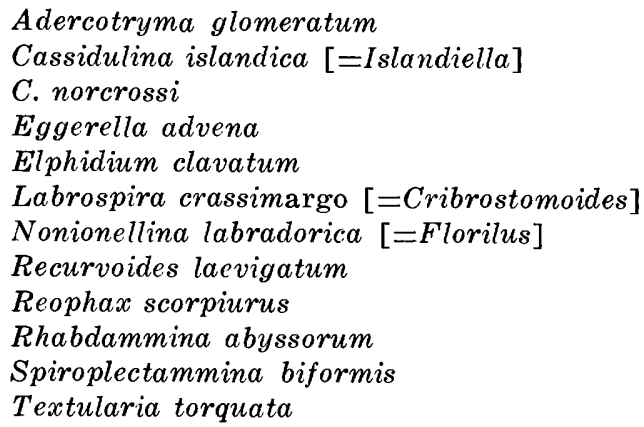

The major species found by Slobodin and Tamanova (1972) that were not found by us (or not identified by these names) are Alveolophragmium karaensis Stschedrina, Hyperammina bradyi Stschedrina, Proteonina atlantica Cushman, Trochamminella bullata Höglund, and Trochamminula fissuraperta Stschedrina. The number of species found by these authors, as well as their diversity, is comparable with our present samples.

In the same report, Slobodin and Tamanova also set down salinity and temperature tolerances for 44 selected nonagglutinated species. They then drew graphs representing interpreted changes in salinity, depth, and temperature in the upper (unconsolidated) parts of the cores they studied, and, for two cores, the lower (consolidated) parts as well. These graphs (Slobodin and Tamanova, 1972, text figs. 2 and 3, p. 32,33 ) represent change from a shallow brackish sea to the present normal marine environment of the shelf sea accompanied by cooling temperatures. All but one of the core graphs show this change to have been fluctuating. The indications of these earlier periods of shallow and brackish deposition are chiefly a decrease of the species at the tops of the cores accompanied by significant differences in their proportions.

Iqbal (1973) studied the sediments and Foraminifera in 40 grab samples from M'Clure Strait, mostly at depths between 250 and $400 \mathrm{~m}$. He recognized three thanatotopes: one exclusively arenaceous that decreases in number away from shore and that seems to prefer finer grained substrates; one predominantly calcareous that increases away from shore and is found on silty and sandy substrates; and a third thanatotope characterized by a mixture of calcareous and arenceous species.

Iqbal concluded that the distribution of the 74 individual species that he found did not fall into any definite patterns but was more typical of mixing such as might have resulted from extensive turbidity currents and ice-rafting, which are the dominant means of sediment transport on the shallow continental shelf areas of the Arctic.

Finally, in an unpublished 1967 University of Wisconsin master's thesis by Sarah Stoll that was summarized by Andrew and Kravitz (1974), 34 of the same samples that we studied were analyzed statistically for their foraminifer content. These samples were restricted to the northern part of the Kara Sea (north of $76^{\circ} \mathrm{N}$ ). All were taken within two north-trending open-ended troughs-St. Ann Trough near Franz Joseph Land and Voronin Trough near Severnaya Zemlya-that are separated by the shallow Central Kara Plateau upon which two small islands rise above the sea surface.

Stoll based her analyses on the 19 most abundant species found in the samples, and our subsequent findings agree in general with her results: arenaceous species are predominant over calcareous ones; individual samples are characterized by low diversity and high dominance of a single species, such dominant species being different from sample to sample. In addition, she noted that in the deep troughs she studied, abundance appears to be directly proportional to bottom temperature and $\mathrm{pH}$ and inversely related to oxygen content, free nitrogen, and organic 
carbon. She concluded that other conditions, including depth, have no linear relationship with abundance and that this variable relationship may be due to the complexity of current patterns, which prevent bottom temperature from being inversely proportional to depth in the troughs.

\section{ANALYSES OF FAUNAS}

\section{KARA SEA}

In the Kara Sea we noted 85 species, only 10 of which were found as major components in more than one sample:

Aschemonella scabra

Cribrostomoides crassimargo

C. subglobosus

Globigerina pachyderma

Hyperammina elongata

Psammosphaera fusca

Reophax nodulosus

$R$. scorpiurus

Saccorhiza ramosa

Trochammina nana

Twelve additional species were found in significant numbers but each species was found in only one sample:

Cornuspira involvens Cruciloculina ericsoni

Dentalina baggi

Elphidium orbiculare

Globigerina bulloides

Globigerinita glutinata

Nonionella turgida digitata

Patellina corrugata

Psammosiphonella crassatina

Pullenia bulloides

Robertina arctica

Trochammina conica

The following 28 species have scattered occurrences, as shown in table 1 , and, with a few exceptions (indicated by asterisks), are not abundant or dominating:

\footnotetext{
Adercotryma glomeratum

Ammodiscus gullmarensis

Astrononion gallowayi

Buccella inusitata

Cassidulina norcrossi

*Cibicides lobatulus

Cribrostomoides jeffreysi

Elphidium clavatum

Florilus labradoricus

*Islandiella helenae

*I. islandica

Jaculella acuta

Melonis zaandamae

* Pelosina cylindrica

*Planispirinoides bucculentus

Pyrgo williamsoni
}

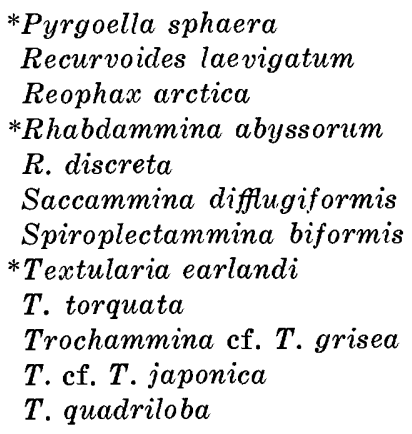

*Pyrgoella sphaera

Recurvoides laevigatum

Reophax arctica

*Rhabdammina abyssorum

$R$. discreta

Saccammina diffugiformis

Spiroplectammina biformis

* Textularia earlandi

T. torquata

Trochammina cf. T. grisea

$T$. cf. T. japonica

T. quadriloba

The remaining 35 species were found as single or rare specimens in one or a few stations in the Kara Sea :

Angulogerina fluens

Biloculinella globula

Bulimina exilis

Cornuspira planorbis

Dentalina frobisherensis

Eggerella advena

Elphidiella hannai

Elphidium bartletti

E. frigidum

Fissurina kerguelenensis

$F$. marginata

F. serrata

Globobulimina auriculata

Globulina glacialis

Hemisphaerammina marisalbi

Hormosina sp.

Hyperammina friabilis

Lagena hispidula

L. laevis

Laryngosigma hyalascidea

Oolina melo

Pateoris haucrinoides

Placopsilina bradyi

Protoschista sp.

Psammatodendron arborescens

Pyrgo fornasinii

Quinqueloculina akneriana

Reophax dentaliniformis

R. guttifer

Rosalina globularis

Saccammina sphaerica

Spirillina vivipara

Thurammina papillata

Triloculina trihedra

Trochammina sp.

\section{GREENLAND SEA}

In the Greenland Sea we noted 75 species, only 8 of which were found as major components in more than one sample:

Cibicides bradii (deep)

Cribrostomoides subglobosus

Eponides tener

Globigerina pachyderma

Psammosphaera fusca (shallow)

Pyrgo vespertilio 
Rhabdammina abyssorum

Saccorhiza ramosa

Found in significant numbers, but mostly in single samples, are Pelosina cylindrica, Pyrgo rotalaria, and Rhabdammina discreta.

The following 29 species have scattered occurrences, as shown in table 1 , and, with a few starred exceptions, are not abundant or dominating:

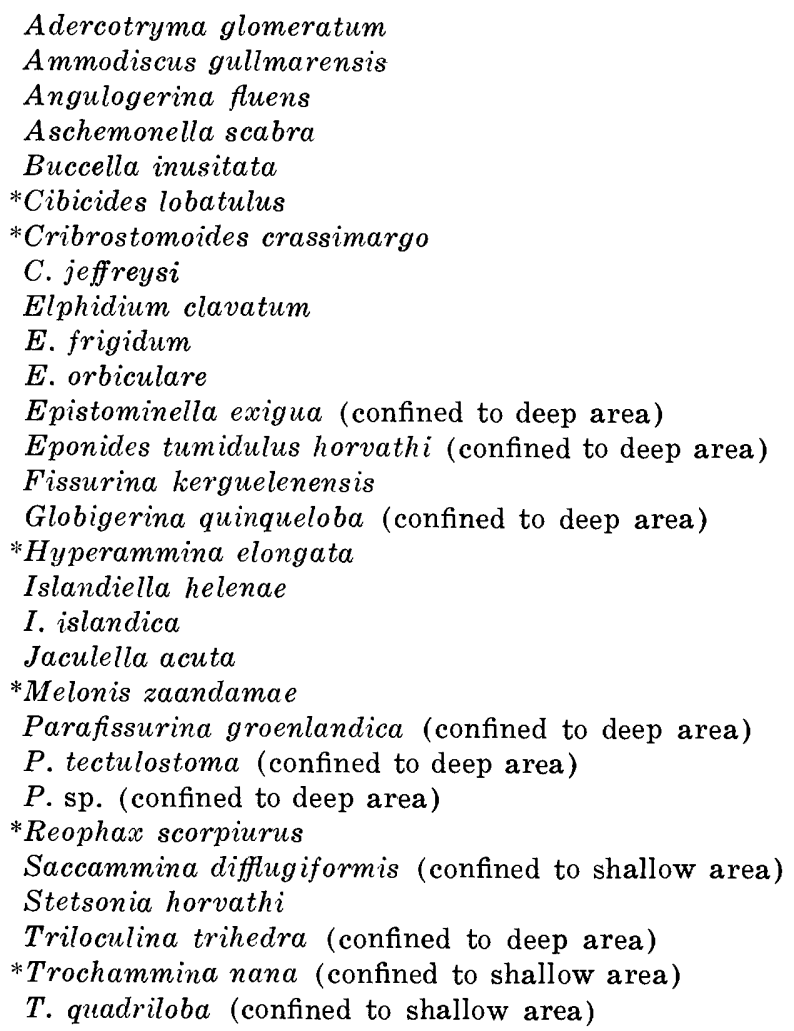

The remaining 35 species from the Greenland Sea were found as single or rare specimens in one or a few stations:
Astacolus planulatus
Astrononion gallowayi
Bolivina rhomboidalis
Cassidulina norcrossi
C. subglobosa
Cornuspira lacunosa
Dentalina baggi
D. decepta
D. frobisherensis
Elphidiella arctica
Eponides repandus
Fischerina sp.
Fissurina marginata
Florilus labradoricus
Hormosina sp.
Hyperammina friabilis
Lagena distoma
L. hispidula
Oolina hexagona
O. lineata
o. melo

Psammatodendron arborescens

Psammosiphonella crassatina?

Pseudononion sp.

Pullenia bulloides

Quinqueloculina akneriana

Recurvoides laevigatum

Reophax guttifer

Textularia earlandi

T. torquata

Tolypammina schaudinni

Trochammina conica

T. cf. T. grisea

$T$. cf. $T$. japonica

Turrispirillina arctica

\section{COMPARISON OF THE KARA AND GREENLAND SEAS FAUNAS}

The combined faunas total 111 species, the two faunas having 50 species in common plus 36 species found exclusively in the Kara Sea and 25 exclusively in the Greenland Sea. Two comparatively abundant species (Reophax nodulosus and Spiroplectammina biformis) were among those found only in the Kara Sea. On the other hand, the Greenland Sea contains two different faunas, the one from shallower water is quite similar to that of the Kara Sea, and the one from deeper water comprises in large part several species not found, or found only rarely, in the Kara Sea, such as Epistominella exigua, Eponides tener, E. tumidulus horvathi, Cibicides bradii, Pyrgo vespertilio, Triloculina trihedra, and the three species of Parafissurina.

The fauna in the Kara Sea seems not to be significantly different from that of comparable depths reported from other parts of the Arctic. It is, as already pointed out, very similar to that of the shallower samples from the Greenland Sea. The assemblages in the deeper samples from the Greenland Sea, likewise, are typical of those from comparable depths in the Arctic Basin.

Comparisons with Antarctic assemblages of comparable depths, however, show some generic similarities, but few species, other than cosmopolitan ones, are the same in the two regions.

\section{DIVERSITY AND DENSITY}

Diversity can be taken as a measure of different features of a fauna. Most simply, it can be measured as the number of species in an assemblage; that is, 5 species or 50 species. But this measure of diversity does not take into account different abundances and is extremely dependent upon size of sample. Gibson and Buzas (1973) gave as an example one assemblage of five species having its species in the proportions of $0.90,0.04,0.03,0.02$, and 0.01 and another 
having proportions of $0.46,0.26,0.16,0.09$, and 0.03 . The second example would be regarded as having a greater diversity. A sample in which individuals are evenly distributed among the species gives a higher diversity value than a sample strongly dominated by one species, and the addition of rare species changes the diversity value only slightly.

Although the total number of species is the simplest measure of diversity, such a measure is extremely dependent upon size of the sample. For precise measurement of diversity, such as discussed by Buzas and Gibson (1969), it is necessary to work with a standard-size sample (or one that can be prorated to a standard size) and to determine, by splitting if necessary, the total population.

An approximate measure of diversity can be taken as the number of species whose proportions total 95 percent of the total population (Walton, 1964, p. 213) or 90 percent (Poag, 1975, oral commun.) Although our samples are not of uniform size and have not been picked clean, we have chosen to record a crude approximation of diversity by the latter method for several of our samples. Most of our samples are moderately to strongly dominated by one or several species. The few that are not so dominated usually have a larger number of species, as well as a greater diversity. The following tabulation lists five of the samples of greater diversity in order of number of specimens mounted:

\begin{tabular}{|c|c|c|}
\hline $\begin{array}{l}\text { Samples of } \\
\text { this study }\end{array}$ & $\begin{array}{l}\text { Total number } \\
\text { of species }\end{array}$ & $\begin{array}{l}\text { Number of species } \\
\text { making up } 90 \text { percent } \\
\text { of the population }\end{array}$ \\
\hline Kara $77 \ldots$ & 22 & 15 \\
\hline Kara 122 & 21 & 11 \\
\hline Greenland 3 & 19 & 10 \\
\hline Kara 106 & 25 & 15 \\
\hline Greenland 16 & 24 & 19 \\
\hline
\end{tabular}

Slobodin and Tamanova (1972) recorded quantitatively the specimens they found in six cores in the Kara Sea. With only one exception, they found their richest assemblages in the top sample of each core. For comparison with our samples, we have calculated an approximation of the diversity for the top sample of each of their cores, tabulated below:

\begin{tabular}{ccc}
\hline $\begin{array}{c}\text { Samples of Slobodin } \\
\text { and Tamanova (1972) } \\
\text { (core tops) }\end{array}$ & $\begin{array}{c}\text { Total number } \\
\text { of species }\end{array}$ & $\begin{array}{c}\text { Number of species } \\
\text { making up } \\
90 \text { percent } \\
\text { of the population }\end{array}$ \\
\hline 5 & 22 & 11 \\
27 & 26 & 12 \\
40 & 24 & 13 \\
104 & 7 & 5 \\
175 & 21 & 13 \\
\hline
\end{tabular}

D. L. Clark (Jan. 6, 1977, written commun.) pointed out that density figures can be strongly biased by shock waves preceding piston coring devices that blow away 10 to $25 \mathrm{~cm}$ of sediment from the surface where the coring device makes contact, so that the modern living population of the sea bottom is not represented in the core tops. This bias has been recognized by comparison between core tops from piston cores and those from box cores where the effects of shock waves are not felt. Even with this allowance, foraminifer populations on the floor of arctic seas are less dense than those in most other regions.

In discussing Foraminifera population densities of the Arctic Ocean, Clark and others (1975, p. 63) calculated an approximate figure of 63 benthonic individuals per square meter as an average. Further speculations regarding lifespan, under conditions not conducive to reproduction of Foraminifera, led these authors to arrive at the figure of two live individuals per square meter during times of faunal scarcity (Clark and others, 1975, p. 64). They further suggest that this population density may be approximated spatially by one cow in 1,440 acres of pastureland. During times of maximum population the figure may rise to as much as 280 live individuals per square meter, still far from an abundant count when compared with the average density of 10,000 tests per square meter on the outer shelf of the Gulf of Mexico (Loeblich, Tappan, and others, 1964, p. C119). Thus, the Arctic regions appear to be very sparsely settled with Foraminifera.

This general rule of increase in density and diversity has exceptions from the Arctic to the tropics. Gibson and Buzas (1973, p. 217) found low diversities south of Nova Scotia, in the Gulf of Maine, and on Browns and Georges Banks as well as in delta areas of the Gulf of Mexico; they attributed the anomalous figures to the environmental regimes being different from adjoining areas.

\section{SUMMARY}

The typical fauna known from shelf seas of the Arctic regions is well represented in the northern and western parts of the Kara Sea and in the northern part of the Greenland Continental Shelf. Its distinguishing characteristics are its sparseness, its erratic distribution, its low diversity, and the strong dominances present in many of the samples. The benthonic Foraminifera that compose the bulk of the fauna are almost exclusively agglutinated and mostly large and robust. In addition, the ubiquitous 
planktonic species of the Arctic (Globigerina pachyderma) and various large robust miliolids make up most of the balance of the assemblage.

The faunas in 17 samples from the deeper areas beyond the Continental Shelf in the Greenland Sea, on the other hand, are distinctly different from the Continental Shelf faunas. Although they share sparseness, erratic distribution, and low diversity with the shelf faunas, and have half of their species in common, their individual samples seem not to be as strongly dominated by one or several species as the shelf samples are. Moreover, the large agglutinated Foraminifera do not occupy as prominent a position in these deeper sediments. Instead, smaller calcareous forms are characteristic.

\section{FAUNAL REFERENCE LIST}

The following alphabetical list of species will facilitate reference to the original description or to a descriptive or systematic treatise where each species is discussed. For each species that is illustrated, a reference to the plates is included. The samples in which each species was found may be determined by referring to table 1.

Adercotryma glomeratum (Brady). Loeblich and Tappan, 1953 , p. 26, pl. 8, figs. 1-4. (Pl. 1, fig. 8).

Relatively small compact form distinguished by its longer dimension being parallel with its axis of coiling, and its aperture scarcely discernible.

Ammodiscus gullmarensis Höglund. Todd and Low, 1967, p. 14, pl. 2, fig. 9. (Pl. 1, fig. 4.)

A minute and fragile species. orange in color.

Angulogerina fluens Todd. Todd and Low, 1967, p. 30, pl. 4, fig. 5.

Aschemonella scabra Brady, 1879, p. 44, pl. 3, figs. 6, 7. (Pl. 1, fig. 20.)

In this genus the axis of the test is branching and irregular. The chambers are irregularly bulbous. The wall is relatively thin and fragile, coarse and rough or fine and smooth, depending on the coarseness of the sediment in which the animal lived. Each chamber has multiple apertures, or broken-off connections to other chambers. The species is most often represented by disjointed segments.

Brady (1884, p. 272-273) mentioned that the long, many jointed tests are flexible in the fresh condition but become brittle, especially at the stoloniferous tubes between chambers, upon drying. Bathymetry rather than geography appears to be the governing factor in the distribution of Aschemonella. Brady reported the genus in the North and South Atlantic and the North and South Pacific at an average depth of 1,800 fathoms (extremes were 210 and 2,900 fathoms).

Astacolus planulatus Galloway and Wissler. Todd and Low, 1967, p. 22, pl. 3, fig. 5 .

Astrononion gallowayi Loeblich and Tappan, 1953, p. 90, pl. 17 , figs. $4-7$.
Biloculinella globula (Bornemann). Todd and Low, 1967, p. 20, pl. 2, fig. 14 .

A large glossy brown specimen with an apertural flap that fills the aperture.

Bolivina rhomboidalis (Millett). Cushman, 1937, p. 138, pl. 18, fig. 7.

A cosmopolitan species.

Buccella inusitata Andersen, 1952, p. 148, pl., figs. 10, 11.

Bulimina exilis Brady. Loeblich and Tappan, 1953, p. 110, pl. 20, figs. 4, 5. (Pl. 2, fig. 3.)

This minute glassy species looks quite similar to specimens in the Arctic that have been referred to Virgulina cf. V. complanata (Phleger, 1952, pl. 14, figs. 15, 16) and to Cassidella complanata (Vilks, 1969, pl. 3, fig. 18) and, in fact, all three may be the same. The critical structural difference is that Bulimina is triserial throughout; Cassidella is triserial initially, becoming biserial and slightly twisted; and Virgulina is biserial and twisted throughout. These are transitional distinctions that may not hold true.

Cassidulina norcrossi Cushman. Todd and Low, 1967, p. 37, pl. 5, fig. 11.

At a superficial glance, this species can be confused with a species of Lenticulina. However, the loop-shaped aperture is diagnostic.

Cassidulina subglobosa Brady, 1884, p. 430, pl. 54, fig. 17. A cosmopolitan species.

Cibicides bradii (Tolmachoff). Planulina bradii Tolmachoff. Barker, 1960, p. 192, pl. 93, fig. 8.

Similar to Planulina wuellerstorfi (Schwager) but thicker and not evolute on the umbilical side. Compared to Cibicides rugosa (Phleger and Parker, 1951, p. 31), which Barker suggested might be a synonym, these are less convex on the nonspiral side, and the rugose ornamentation is less strongly developed. The generic distinction between Planulina and Cibicides appears to be that the former is partially evolute rather than involute on the umbilical side, and that it is more strongly compressed than Cibicides. But both these morphologic features are gradational, and even some specimens of a single species could be placed in either genus. The present specimens are closer to Cibicides than to typical Planulina.

Cibicides lobatulus (Walker and Jacob). Todd and Low, 1967, p. 34, pl. 5, figs. 1, $2,4$.

Cornuspira involvens (Reuss). Todd and Low, 1967, p. 21, pl. 2, fig. 11. (Pl. 2, fig. 18.)

Cornuspira lacunosa Brady, 1884, p. 202, pl. 113, fig. 21. (Pl. 2, fig. 19.)

This species is characterized by crude longitudinal striations.

Cormuspira planorbis Schultze. Todd and Low, 1961, p. 15, pl. 1, fig. 9 .

A cosmopolitan species, but more characteristic of shallow than deep water.

Genus Cribrostomoides Cushman, 1910

The most comprehensive history of the genus Cribrostomoides was given by Frizzell and Schwartz (1950). In addition to outlining the complex taxonomic problem, they illustrated the range of variation in the aperture. We agree that typically the aperture is an elongate slit near the base, but within the face, of the last-formed chamber. Later irregularities may develop in the apertural lip, or within the elongate slit, simulating multiple apertures. This phenomenon occurs commonly in the type species Cribrostomoides subglobosus (G. O. Sars) but has not 
been reported in other species such as $C$. crassimargo (Norman).

Cribrostomoides Cushman, emend. Todd and Low

Test free, involute, planispiral-streptospiral, symmetrical to asymmetrical; periphery rounded; chambers simple, increasing in size as added; wall nonalveolar, arenaceous, fine to coarse grained; aperture interio-areal, elongate slit with upper and lower lips of finer material which may touch at intervals making a series of irregular openings.

The principal refinement to our emendation is the test's inclination to be asymmetrical. The original designation of Cribrostomoides Cushman (1910, p. 108) differed from Haplophragmoides Cushman (1910, p. 99) only in its apertural characters. Loeblich, Tappan, and others, (1964, p. C225) also gave this as the only distinguishing feature with no further diagnosis.

However, all species we have studied within the genus have a lack of symmetry in their coiling. The asymmetry grades from a slight warping tendency in the axis of coiling in specimens of $C$. crassimargo (Norman) to streptospiral coiling in end forms of C. subglobosus (G. O. Sars), the type species. This is evident not only in thin section (Henbest, 1931, pl. 12, fig. 2 [Cushman Colln. No. 24771]) but also in exterior appearance of the umbilici, which may be unequal. In the more twisted individuals, one umbilicus is flush and the other is slightly depressed.

In his 1931 study of wall structure, Henbest illustrated thin sections of "Cribrostomoides bradyi Cushman" ( $\mathrm{pl}$. 12, figs. 1, 2), and his figure 1 has been republished several times to illustrates the lack of subdivision of the chambers (Maync, 1952, text fig. B2; Loeblich, Tappan, and others, 1964, text fig. 136.2). Although Henbest's figure 2 revealed the tendency to streptospiral coiling, this feature was neglected by subsequent authors in their consideration of generic characters of Cribrostomoides.

Echols $(1971$, p. 162) noted the coiling abnormalities in his suite of specimens of Cribrostomoides subglobosus from the Antarctic. We do not agree, however, that the degree of twist in Cribrostomoides warrants suppressing the more contorted genus Recurvoides Earland, 1934, as was recommended by Echols.

Our reason for maintaining both Cribrostomoides and Recurvoides as distinct genera is that the type of coiling is fundamentally different. Recurvoides was originally described as consisting of two planispiral and partially embracing convolutions set at approximately $90^{\circ}$ from each other so that the edge of the earlier whorl remains as a bulge from one umbilicus of the later whorl. Good illustrations of the type species of both genera by Loeblich, Tappan, and others, (1964)-Cribrostomoides subglobosus (fig. 136.1, USNM 12657a) and Recurvoides contortus (fig. 136.9, USNM 640980)-convincingly show their distinctions.

Cribrostomoides crassimargo (Norman). Todd and Low, 1967, p. 15, pl. 1, fig. 24.

Some of our specimens are attached to Psammosphaera fusca, or it may be that specimens of $P$. fusca were incorporated in the wall as sand grains would be.

Cribrostomoides jeffreysi (Williamson). Todd and Low, 1967, p. 15, pl. 1, fig. 21. (Pl. 1, fig. 3.)

A delicate, thin-walled species with inflated chambers, strongly depressed umbilicus, and broad low aperture.

Cribrostomoides subglobosus (G. O. Sars). (Pl. 1, fig. 7.) Synonymy :
Cribrostomoides bradyi Cushman. Henbest, 1931, pl. 12, figs. $1,2$.

Recurvoides subglobosus (G. O. Sars). Uchio, 1960, p. 52 , pl. 1, figs. 26, 27. [See complete synonymy.]

Cribrostomoides subglobosum (G. O. Sars). Loeblich and Tappan, 1964, p. 225, figs. 136.1, 136.2. Echols, 1971, p. 162 , pl. 3 , figs. 8,9 .

Haplophragmium latidorsatum Bornemann. Flint, 1899, p. 276 , pl. 20 , fig. 1 .

Test free, nearly circular, involute, planispiral-streptospiral, umbilical area may be slightly deeper on one side depending on degree of twist, periphery rounded; chambers simple, not subdivided, increasing in size as added, about six visible in last coil; sutures straight, mostly flush in early part, slightly depressed between later chambers; wall generally of firmly cemented fine sand and a few coarser clear quartz grains, surface irregular but smoothly finished; aperture an interio marginal slit, short, curved, with lip composed of fine cementing material, slit becoming longer in larger specimens with tendency of lip to seal intermittently, simulating multiple apertures.

Cruciloculina ericsoni Loeblich and Tappan, 1957, p. 234, pl. 74, figs. 3-7. (Pl. 2, fig. 13.)

Dentalina baggi Galloway and Wissler. Todd and Low, 1967, p. 22, pl. 3, figs. 10, 11 .

Dentalina decepta (Bagg). Todd and Low, 1967, p. 22, pl. 3, fig. 6.

Dentalina frobisherensis Loeblich and Tappan, 1953, p. 55, pl. 10, figs. 1-9.

Eggerella advena (Cushman). Loeblich and Tappan, 1953, p. 36, pl. 3 , figs. $8-10$.

This shallow-water species is rare in our samples, most of which were taken from water too deep for it.

Elphidiella arctica (Parker and Jones). Todd and Low, 1967, p. 34 , pl. 4, fig. 15 .

Elphidiella hannai (Cushman and Grant). Cushman, 1941, p. 35 , pl. 9, figs. 5,6 .

The taxonomy of this species, of which we have only one worn and orange-stained specimen, is not firmly established (see Hopkins and others, 1974, p. 459, 461). Their suggestion (table 3 on p. 454) that it is presently restricted to the Pacific side of the Arctic is not supported by the occurrence of the similar if not identical species Elphidiella tumida Gudina in middle and late Pleistocene beds of western Siberia (Gudina and Evserov, 1973, p. 107, pl. 14, fig. 3 ; pl. 15, figs. 1, 2 ).

Elphidium bartletti Cushman. Loeblich and Tappan, 1953, p. 96, pl. 18, figs. 10-14.

Elphidium clavatum Cushman. Todd and Low, 1967, p. 33, pl. 4, figs. 16, 17.

Elphidium frigidum Cushman. Todd and Low, 1967, p. 33, pl. 4, figs. 9, 10.

Elphidium orbiculare (Brady). Loeblich and Tappan, 1953, p. 102, pl. 19, figs. 1-4.

Epistominella exigua (Brady). Todd, 1965, p. 30, pl. 10, fig. 1. (Pl. 2, fig. 11.)

This minute species appears to be widespread in deep waters of both polar and equatorial regions.

Eponides repandus Montfort. Todd, 1965, p. 20, pl. 7, figs. 3, 4.

The one specimen we have of this widespread species is the compact repandus-form. It is broken and shows the effect of some boring predator. 
Eponides tener (Brady). Vilks, 1969, p. 50, pl. 3, fig. 16. (Pl. 2, fig. 10.)

This widespread species is characteristic of deep waters. It is smooth and polished, unornamented, and very neatly constructed. The sutures meet in a star pattern at the center of the ventral side. The dorsal sutures, also, are radiating, not slanted. The aperture is bordered by a raised rim.

Eponides tumidulus horvathi Green, 1960, p. 71, pl. 1, fig. 5. (Pl. 2, fig. 7.)

Test minute for the genus, dorsally high spired, ventrally open at the umbilicus; periphery rounded and lobulated; chambers inflated, very gradually increasing in size as added, six to eight composing the final whorl; sutures distict, slightly indented, radiating, not oblique; wall smooth, polished, brownish-orange in color, irridescent; aperture inconspicuous under the ventral edge of the final chamber. Greater diameter $0.11-0.23 \mathrm{~mm}$; height 0.06 $0.10 \mathrm{~mm}$.

This Arctic form seems closely related to Brady's species described as Truncatulina tumidulus from 2,740 fathoms, off the Canaries. It is similar in almost all respects, even to the brownish color. It differs chiefly in having more chambers per final whorl, in the ventral umbilicus being more widely open, and in lacking limbation of the early dorsal sutures.

Fischerina sp. (Pl. 2, fig. 12.)

The generic separation of Fischerinella from Fischerina on the basis of the coiling being trochospiral instead of planispiral seems inappropriate to us. Hence, we place the involute-evolute specimen we have in Fischerina. It is a thick but flat-coiled form in which only a small bulge of the initial coil shows at the center of the evolute side. Seven chambers comprise the final whorl.

Fissurina kerguelenensis Parr, 1950, p. 305, pl. 8, fig. 7. (Pl. 2, fig. 9.)

This Antarctic species is found also in the Arctic.

Fissurina marginata (Montagu). Loeblich and Tappan, 1953, p. 77 , pl. 14, figs. $6-9$.

Fissurina serrata (Schlumberger). Loeblich and Tappan, 1953, p. 78 , pl. 14, fig. 5 .

Florilus labradoricus (Dawson). Todd and Low, 1967, p. 35, pl. 5, fig. 9.

Globigerina bulloides d'Orbigny. Parker, 1962, p. 221, pl. 1, figs. 1-8.

Globigerina pachyderma (Ehrenberg). Parker, 1962, p. 224, pl. 1, figs. 26-35; pl. 2, figs. 1-6.

Globigerina quinqueloba Natland. Parker, 1962, p. 225, pl. 2, figs. 7-16.

Globigerinita glutinata (Egger). Parker, 1962, p. 246, pl. 9, figs. 1-16.

Globobulimina auriculata (Bailey). Todd and Low, 1967, p. 26, pl. 3, fig. 38.

Globulina glacialis Cushman and Ozawa. Cushman, 1948, p. 50, pl. 5, figs. $15,16$.

Hemisphaerammina marisalbi (Stschedrina). Iridia marisalbi Stschedrina, 1962, p. 57, text figs. 4, 5.

Specimens formerly called Webbinella are placed in the genus Hemisphaerammina that was erected when it was found that the type species of Webbinella was in reality an attached polymorphinid. H. marisalbi, described from the White Sea, was originally placed in the genus Iridiella, which, like "Webbinella," consisted simply of a thickwalled, agglutinated hemispherical chamber attached to a rigid support. Our material consists of two adjacent specimens, orange and rather coarse grained, attached to a broken fragment of an arenaceous tube.

Hormosina sp. of Parker, 1952, p. 395, pl. 1, figs. 8, 9. (Pl. 1, fig. 15.)

Parker reported and illustrated a rare species found off Portsmouth, N.H., consisting of 3 or 4 chambers. We believe we have the same species occurring very rarely in both seas. Its two or three globular chambers are joined by tightly constricted necks, and the neck of the final chamber is slightly drawn out. This species is similar to Reophax guttifer, but its chambers are more globular and less separated from one another, and the wall is built of finer grains.

Hyperammina elongata Brady. Loeblich and Tappan, 1953, p. 19, pl. 1, fig. 6. (Pl. 1, fig. 18.)

Most of our specimens of this species lack the bulbous initial end. But the smoothly finished wall in which angular and moderately coarse grains are set in a fine orange matrix is easily recognizable even in small broken fragments. In his discussion of this species in the Challenger Report, Brady (1884, p. 257, pl. 23, figs. 4, 7-10) included both rough-surfaced and smooth, polished ones in his concept of the species. Since then, others have separated these two kinds into $H$. elongata for the rough-surfaced ones and $H$. laevigata for the smooth, polished ones. Höglund (1947, p. 66-68, text figs. 22-31) presented a convincing argument for distinguishing between these two species. Our present material seems inadequate for clear separation. Hence, we use $H$. elongata for this slender tubular species that has a thin hard wall.

Hyperammina friabilis Brady, 1884, p. 258, pl. 23, figs. 1-3, $5,6$.

This species is large, stout, and has a thick wall of rough and friable texture.

Genus Islandiella Nørvang, 1958

The distinction between Cassidulina and Islandiella has been clarified by Feyling-Hanssen and Buzas (1976); namely, that Islandiella possesses a free tongue, the extension of the internal tooth, that projects out of the aperture, rather than a platelike lip attached to the base of the aperture from which there is no connection back to the aperture of the preceding chamber.

Islandiclla helenae Feyling-Hanssen and Buzas, 1976, p. 155, text figs. 1-4.

Studies by Feyling-Hanssen and Buzas (1976) show that the widespread Arctic species reported as Cassidulina teretis Tappan (Loeblich and Tappan, 1953, p. 121, and many other authors) is not the same as the types of Cassidulina teretis from the Pleistocene of northern Alaska The modern Arctic species belongs in Islandiella, but the Pleistocene one is a true Cassidulina.

Islandiella islandica (Nørvang). Loeblich and Tappan, 1953, p. 118 , pl. 24 , fig. 1 .

Our specimens, ranging from 0.16 to $0.19 \mathrm{~mm}$, are somewhat smaller than normal for this species. Vilks $(1969, \mathrm{p}$. 49) found this species absent in depths shallower than about $200 \mathrm{~m}$.

Jaculella acuta Brady, 1884, p. 255, pl. 22, figs. 14-18. (Pl. 1, fig. 17.)

Jaculella differs from Hyperammina in being tapering rather than cylindrical. Otherwise, they are quite similar and have the same kind of smooth and hard wall surface. In some specimens the axis of the test is arcuate; in others, straight. 
Lagena distoma Parker and Jones. Todd and Low, 1967, p. 24, pl. 3, fig. 18.

Lagena hispidula Cushman, 1913, p. 14, pl. 5, figs. 2, 3.

This cosmopolitan species differs from $L$. laevis in that the greatest diameter is midway of the chamber rather than toward the base and the body of the test does not merge into the long slender neck. From the Arctic species, L. flatulenta Loeblich and Tappan, it differs in its wall surface being finely hispid instead of smooth hyaline.

Lagena laevis (Montagu). Todd and Low, 1967, p. 24, pl. 3, fig. 17. (Pl. 2, fig. 1.)

Laryngosigma hyalascidia Loeblich and Tappan, 1953, p. 83, pl. 15, figs. 6-8. (Pl. 2, fig. 2.)

Melonis zaandamae (van Voorthuysen). Nonion zaandamae (van Voorthuysen). Loeblich and Tappan, 1953, p. 87, pl. 16, figs. 11, 12. (Pl. 2, fig. 8.)

Nonionella turgida digitata Nørvang. Todd and Low, 1967, p. 36 , pl. 5, fig. 8 .

Oolina hexagona (Williamson). Loeblich and Tappan, 1953, p. 69 , pl. 14, figs. $1,2$.

Oolina lineata (Williamson). Loeblich and Tappan, 1953, p. 70, pl. 13, figs. 11-13.

Oolina melo d'Orbigny. Loeblich and Tappan, 1953, p. 71, pl. 12, figs. 8-15.

Parafissurina groenlandica (Stschedrina). Androsova, 1962, p. 108, text fig. 3. (PI. 2, fig. 6.)

Parafissurina tectulostoma Loeblich and Tappan, 1953, p. 81, pl. 14, fig. 17. (Pl. 2, fig. 5.)

Parafissurina sp. (Pl. 2, fig. 4.)

Test compressed, circular in outline except for the protruding aperture, moderately inflated; periphery subacute; wall smooth, opaque; aperture hooded, as typical of this genus. At first glance this could be one of the several species of Fissurina that are characteristically found in the Arctic seas.

Patellina corrugata Williamson. Loeblich and Tappan, 1953, p. 114, pl. 21, figs. 4,5 .

Pateoris hauerinoides (Rhumbler). Loeblich and Tappan, 1953 , p. 42 , pl. 6 , figs. $8-12$; text figs. $1 \mathrm{~A}, \mathrm{~B}$.

A quinqueloculine Miliolinella (=Scutuloris) without an apertural flap. In classifying miliolids, apertural characters seem to be more important than type of initial coiling.

Pelosina sp.

Rare specimens, in which a thin flexible chitinous lining of an elongate tube, coated loosely with sand, collapses when dry into a sandy ribbon.

Placopsilina bradyi Cushman and McCulloch, 1939, p. 112, pl. 12, figs. 14, 15.

A cosmopolitan species.

Planispirinoides bucculentus (Brady). Parr, 1950, p. 287, pl. 6, figs. 1-6; text figs. 1-5. (Pl. 2, fig. 17.)

Protoschista sp.

A branching Reophax, our specimen is large, rugged, and coarse grained.

Psammatodendron arborescens Norman. Barker, 1960, p. 58, pl. 28, figs. 12, 13.

Slender, irregular, finely arenaceous tubes.

Psammosiphonella crassatina (Brady). Astrorhiza crassatina Brady, 1884, p. 233, pl. 20, figs. 1-9.

Avnimelech (1952, p. 64) erected Psammosiphonella to include certain species formerly placed in the tubular genera Bathysiphon, Marsipella, Astrorhiza, and Rhab- dammina. Psammosiphonella differs from the first two of these genera in that the wall is composed of mineral grains, mostly quartz, instead of sponge spicules. It differs from the other two genera in lacking radiating arms. Whether or not these distinctions are valid remains to be seen, but that question is beyond the scope of this study. Nevertheless, it seems convenient to use this generic name for the friable species originally included under Astrorhiza, which was described from dredgings at 640 fathoms in the Faröe Channel. This species differs from other species of Astrorhiza in lacking distinct arms. Our specimens are large $(4-5 \mathrm{~mm})$, coarse-grained, and so loosely cemented and fragile that it is impossible to determine the size of the living cavity, the wall thickness, and whether the wall was solid or labyrinthic, and whether both ends of the tube were open.

Psammosphaera fusca Schulze. Brady (part), 1884, p. 249, pl. 18, figs. 1, 5-8.

This species normally consists of a single arenaceous sphere, but specimens may be attached to foreign objects or even to each other. Its rough but firm surface, smoothly finished inside, is like that of Saccammina sphaerica M. Sars from which it differs in lacking a definite aperture. It appears to be cosmopolitan in deep waters.

Pseudononion sp.

This tiny, compact but inflated form of about seven chambers has a depressed and open umbilicus. Greater dimension $0.17-0.23 \mathrm{~mm}$.

Pullenia bulloides (d'Orbigny). Todd, 1965, p. 48, pl. 18, fig. 6.

Pyrgo fornasinii Chapman and Parr. Barker, 1960, p. 4, pl. 2, fig. 7. (Pl. 2, fig. 16.)

This circular Pyrgo has a wide and almost noncurving flap filling the aperture that results in a narrow elongate apertural slit. The test is large, well-rounded, and plump. Pyrgo rotalaria Loeblich and Tappan, 1953, p. 47, pl. 6, figs. 5, 6. (Pl. 2, fig. 20.)

Pyrgo vespertillio (Schlumberger). Todd and Low, 1967, p. 21, pl. 2, fig. 24. (Pl. 2, fig. 21.)

Pyrgo williamsoni (Silvestri). Loeblich and Tappan, 1953, p. 48, pl. 6, figs. 1-4. (Pl. 2, fig. 14.)

Pyrgoella sphaera (d'Orbigny). Todd and Low, 1967, p. 21, pl. 2, fig. 20. (Pl. 2, fig. 22.)

Quinqueloculina akneriana d'Orbigny. Todd and Low, 1967, p. 18 , pl. 2 , fig. 22 .

Recurvoides laevigatum Höglund, 1947, p. 150, pl. 11, fig. 6; text figs. 117-119.

Test minute for the genus, compressed, periphery rounded, not lobulated; chambers indistinct, not inflated, five or six making up the final whorl; sutures indistinct, straight not much indented; wall composed of rather large grains for the small size of the entire test, smoothly finished, polished orange in the early part of the test, clear later; aperture not observed in the unbroken final chamber, a very small opening into the penultimate chamber is observable near the base of the septa in two specimens in which the final chamber is broken. Greater diameter 0.20 $\mathrm{mm}$; thickness $0.10 \mathrm{~mm}$.

Reophax arctica Brady. Loeblich and Tappan, 1953, p. 21, pl. 1, figs. 19, 20.

Reophax dentaliniformis Brady, 1884, p. 293, pl. 30, figs. 21, 22.

A more delicate species than $R$. scorpiurus Montfort and having a straight, not curved, axis. 
Reophax guttifer Brady. Brady, 1884, p. 295, pl. 31, figs. 10-15. (Pl. 1, fig. 14.)

Reophax nodulosus Brady, 1884, p. 294, pl. 31, figs. 1-9. (Pl. 1, fig. 16.)

Reophax scorpiurus Montfort. Todd and Low, 1967, p. 14, pl. 1, figs. 13, 14.

Rhabdammina abyssorum M. Sars. Brady, 1884, p. 266, pl. 21, figs. 1-13. (Pl. 1, figs. 13, 19.)

Built of fine to coarse sand grains, the surface is rough but firmly cemented.

Rhabdammina discreta Brady, 1884, p. 268, pl. 22, figs. 7-10. (PI. 1, fig. 12.)

The surface is identical with that of $R$. abyssorum M. Sars but the test shows constrictions.

Robertina arctica d'Orbigny. Cushman, 1948, p. 61, pl. 6, figs. 16-18.

Rosalina globularis d'Orbigny. Douglas and Sliter, 1965, p. 155 , pl. 2, fig. 2 ; pl. 3, figs. $1-5$; text fig. 2 .

Saccammina diffugiformis (Brady). Reophax difflugiformis Brady, 1884, p. 289, pl. 30, figs. 1-5.

Our specimens are built of moderately coarse grains.

Saccammina sphaerica M. Sars. Brady, 1884, p. 253, pl. 18 figs. 11-17.

Characterized by its produced aperture.

Saccorhiza ramosa (Brady). Hyperammina ramosa Brady, 1884, p. 261, pl. 23, figs. 15-19. (Pl. 1, figs. 21, 22.)

Spirillina vivipara Ehrenberg. Loeblich and Tappan, 1953, p. 112, pl. 21, figs. 2,3 .

Spiroplectammina biformis (Parker and Jones). Loeblich and

Tappan 1953, p. 34, pl. 4, figs. 1-6.

Stetsonia horvathi Green, 1960, p. 72, pl. 1, fig. 6 .

A minute rotaliform species having a transparent wall. Five chambers separated by opaque suture lines comprise the final whorl.

Textularia carlandi Parker. Phleger, 1952, p. 86, pl. 13, figs. $22,23$.

Textularia torquata Parker, 1952, p. 403, pl. 3, figs. 9-11. (Pl. 1, fig. 11.)

Thurammina papillata Brady, 1884, p. 321, pl. 36, figs. 7-18. (PI. 1, fig. 10.)

Tolypammina schaudinni Rhumbler. Parker, 1954, p. 485 pl. 1, fig. 15. (Pl. 1, fig. 9.)

Triloculina trihedra Loeblich and Tappan, 1953, p. 45, pl. 4, fig. 10. (Pl. 2, fig. 15.)

Genus Trochammina Parker and Jones, 1859

This genus is fairly consistently present in our material, but all the species are relatively small and fragile.

Trochammina conica Earland. Phleger, 1952, p. 86, pl. 13, figs. 35,36 . $\mathrm{mm}$.

Trochammina cf. T. grisea Earland. (Pl. 1, fig. 1.)

Our specimens, although much smaller, compare well with this flat-spired species described from the Antarctic (Earland, 1934, p. 100, pl. 3, figs. 35-37).

Trochammina cf. T. japonica Ishiwada. (Pl. 1, fig. 2.)

Our specimens are moderately high-spired, and five chambers (or rarely four) make up the final whorl. They seem close to $T$. japonica described from Toyama Bay (Ishiwada, 1950, p. 190, pl., fig. 2).

Trochammina nana (Brady). (PI. 1, figs. 5, 6.)

Haplophragmium nanum Brady, 1884, p. 311, pl. 35 , figs. 6-8.

Trochammina lobata Cuchman, 1944, p. 18, pl. 2, fig. 10.
Trochammina karica Stschedrina, 1946, p. 147, pl. 3, fig. 16.

Test small for the genus, trochoid, composed of 2 to $2 \frac{1}{2}$ whorls, dorsal side flat, ventral side convex but depressed toward the umbilicus, periphery subacute, entire in the early part, lobulated in the later part; chambers, six to eight in the final whorl, depressed dorsally, inflated ventrally and progressively more so as added, the final one extending inward with a large lobe that fills the umbilicus; sutures distinct, dorsal ones flush, curved, and oblique, ventral ones incised, straight, and radial; wall thin, built of large sand grains for the size of the test but smoothly finished and glossy, orange in color; aperture under the umbilical lobe of the final chamber and extending to the periphery. Diameter 0.25 to $0.60 \mathrm{~mm}$; thickness $0.10 \mathrm{~mm}$.

This appears to be a highly variable species in which several different forms have been given different names. Large suites of specimens show the unity of the variants. The features that serve to unite this large plexus of morphologic types are, first, the extreme flatness of the dorsal surface; second, the lobulation of the latter part of the adult whorl; and, third, the lobate extension of the final chamber as a flat tongue into the umbilicus.

The variable features seem to be chiefly the irregularity in shape and disposition of chambers and the degree to which the chambers expand as added. Gradual expansion results in a nearly circular test, and rapid expansion results in an oblong shape.

Trochammina quadriloba Höglund. Trochammina pusilla Höglund, 1947, p. 201, pl. 17, fig. 4; text figs. 183, 184 (renamed T. quadriloba because of homonymy).

Characterized by a pointed dorsal spire and rough surface.

Trochammina sp.

A tiny attached flake, having many chambers. The sutures are straight, not slanted.

Turrispirillina arctica (Cushman). Loeblich and Tappan, 1953 , p. 113 , pl. 21, fig. 1.

\section{REFERENCES CITED}

Andersen, H. V., 1952, Buccella, a new genus of the rotalid Foraminifera: Washington Acad. Sci. Jour., v. 42, no. 5, p. 143-151, figs. 1-13.

Andrew, John A., and Kravitz, Joseph H., 1974, Sediment distribution in deep areas of the northern Kara Sea, in Herman, Yvonne, ed., Marine geology and oceanography of the arctic seas: New York, Springer Verlag, p. 231-256, figs. 1-16, tables 1-6.

Androsova, V. P., 1962, Foraminifery donnykh otlozhenij zapadnoj chasti polyarnogo bassejna [Benthonic Foraminifera of the western part of the Polar Basin], in Issledovaniia po programme Mezhdunarodnogo Geofizicheskogo goda, L. G. Vinogradova, ed.: Vses. NauchnoIssled. Inst. Morskogo Ryb. Khoz. i Okean. (VNIRO), Trudy, v. 46, p. 102-117, figs. 1-17, tables 1-4.

Avnimelech, Moshé, 1952, Revision of the tubular Monothalamia: Cushman Found. Foram. Research Contr., v. 3, p. $60-68,1$ pl.

Awerinzew, S., 1911, Zur Foraminiferen-Fauna des Sibirischen Eismeeres: Acad. Imp. Sci. St. Pétersbourg, Cl. Phys.-Math., Mém., ser. 8, v. 29, no. 3, p. 1-27, 1 pl. 
Barker, R. W., 1960, Taxonomic notes on the species figured by $H$. B. Brady in his report on the Foraminifera dredged by H.M.S. Challenger during the years 18731876: Soc. Econ. Paleontologists and Mineralogists Spec. Pub. 9, 238 p., 115 pls.

Basov, V. A., and Slobodin, V. Y., 1965, [Complexes of Recent and late Cenozoic Foraminifera of western Soviet Arctic] in Antropogenovyj Period v Arktike i Subarktike: Nauchno-Issled. Inst. Geologii Arktiki Trudy, v. 143, p. 190-210, figs. 1-18. [In Russian.]

Brady, H. B., 1878, On the reticularian and radiolarian Rhizopoda (Foraminifera and Polycystina) of the North-Polar Expedition of 1875-76: Annals Mag. Nat. History, ser. 5, v. 1, p. 425-440, pls. 20, 21.

-1879 , Notes on some of the reticularian Rhizopoda of the "Challenger" Expedition. I.-On new or little known arenaceous types: Micros. Sci. Quart. Jour., v. 19, new ser., p. 20-63, pls. 3-5.

-1881, On some Arctic Foraminifera from soundings obtained on the Austro-Hungarian North-Polar Expedition of 1872-1874: Annals Mag. Nat. History, ser. 5, v. 8, p. $393-418$, pl. 21 .

1884, Report on the Foraminifera dredged by H.M.S. Challenger, during the years 1873-1876: Challenger Rept., Zoology, v. 9, 814 p., 115 pls.

Buzas, M. A., and Gibson, T. G., 1969, Species diversityBenthonic Foraminifera in western North Atlantic: Science, v. 163 , no. 3862 , p. $72-75$, figs. 1,2 .

Clark, D. L., Larson, J. A., Root, R. E., and Fagerlin, S. C., 1975, Foraminiferal patterns of the Arctic Ocean Pliocene and Pleistocene: Wisconsin Univ., Arctic Ocean Sediment Studies Program 18, Tech. Rept., 94 p., 3 pls. 20 figs.

Cushman, J. A., 1910, A monograph of the Foraminifera of the North Pacific Ocean, Part 1, Astrorhizidae and Lituolidae: U.S. Natl. Mus. Bull. 71, pt. 1, p. 1-134, figs. 1-203.

- 1913, A monograph of the Foraminifera of the North Pacific Ocean, Part 3, Lagenidae: U.S. Natl. Mus. Bull. 71, pt. 3, p. 1-125, pls. 1-47.

-1937, A monograph of the subfamily Virgulininae of the foraminiferal family Buliminidae: Cushman Lab. Foram. Research Spec. Pub. 9, 228 p., 24 pls.

1941, Some fossil Foraminifera from Alaska: Cushman Lab. Foram. Research Contr., v. 17, p. 33-38, pl. 9. 1944, Foraminifera from the shallow water of the New England Coast: Cushman Lab. Foram. Research Spec. Pub. 12, p. 1-37, pls. 1-4.

- 1948, Arctic Foraminifera: Cushman Lab. Foram. Research Spec. Pub. 23, 79 p., 8 pls.

Cushman, J. A., and McCulloch, Irene, 1939, A report on some arenaceous Foraminifera: Allan Hancock Pacific Exped., v. 6, no. 1, p. 1-113, pls. 1-12.

Digas, L. A., 1971, Fauna foraminifer tsentralnoy vozvyshennosti i severo-vostochnoy chasti zapadnogo zheloba Barentseva Morya [Foraminiferal fauna of the central elevation and northeastern parts of the western trough of the Barents Sea], in Voprosy geologii yuzhnogo Urala i Povodzhya [Problems of the geology of the southern Urals and Volga regions], no. 4, pt. 2, Kainozoi [Cenozoic Era]: [Saratov, RSFSR] Izdat. Saratovskogo Univ., p. 179-194, 1 pl., fig. 1.

Douglas, Robert, and Sliter, W. V., 1965, Taxonomic revision of certain Discorbacea and Orbitoidacea (Foraminife- rida): Tulane Studies Geology, v. 3, no. 3, p. 149-164, pls. 1-3, figs. 1,2 .

Earland, Arthur, 1934, Foraminifera. Part 3. The Falklands sector of the Antarctic (excluding South Georgia): Great Britain Colonial Office, Discovery Committee, Discovery Repts., v. 10, p. 1-208, pls. 1-10.

Echols, R. J., 1971, Distribution of Foraminifera in sediments of the Scotia Sea area, Antarctic waters, in Reid, J. L., ed., Antarctic oceanology I: Am. Geophys. Union Antarctic Research Ser., v. 15, p. 93-168, pls. 1-16, figs. 1-22, tables 1-6.

Feyling-Hanssen, R. W., and Buzas, M. A., 1976, Emendation of Cassidulina and Islandiella helenae new species: Jour. Foram. Research, v. 6, no. 2 p. 154-158, figs. 1-4.

Flint, J. M., 1899, Recent Foraminifera. A descriptive catalogue of specimens dredged by the U.S. Fish Commission steamer Albatross: U.S. Natl. Mus. Rept. for 1897, pt. 2 , p. $249-349$, pls. 1-80.

Frizzell, D. L., and Schwartz, Ely, 1950, A new lituolid foraminiferal genus from the Cretaceous, with an emendation of Cribrostomoides Cushman: Missouri Univ., School Mines Metallurgy Bull., Tech. Ser. no. 76, p. 1-12, pl. 1, fig. 1.

Gibson, T. G., and Buzas, M. A., 1973, Species diversitypatterns in modern and Miocene Foraminifera of the eastern margin of North America: Geol. Soc. America Bull., v. 84 , p. $217-238$, figs. 1-17.

Goës, Axel, 1894, A synopsis of the Arctic and Scandinavian Recent marine Foraminifera hitherto discovered: Kgl. Svenska vetenskapsakad. Handl., v. 25, no. 9, p. 1-127, pls. 1-25.

Green, K. E., 1960, Ecology of some Arctic Foraminifera: Micropaleontology, v. 6 , no. 1 , p. 57-78, pl. 1, figs. 1-9, tables 1-6.

Gudina, V. I., and Evserov, V. Ja., 1973, Stratigraphy and Foraminifera of late Pleistocene of Kola Peninsula (in Russion): Akad. Nauk SSSR Sibirsk. Otdeleniye Geologiya i Geofizka [Acad. Sci. USSR-Siberian Branch, Inst. Geology and Geophysics], Trudy 175, p. 1-145, pls. 1-17, figs. 1-14, tables 1-3.

Henbest, L. G., 1931, The species Endothyra baileyi (Hall) : Cushman Lab. Foram. Research Contr., v. 7, p. 90-93, pls. 11 (part), 12.

Höglund, Hans, 1947, Foraminifera in the Gullmar Fjord and the Skagerak: Zool. Bidrag frann Uppsala, v. 26, 328 p., 32 pls., 312 figs.

Hopkins, D. M., Rowland, R. W., Echols, R. E., and Valentine, P. C., 1974, An Anvilian (early Pleistocene) marine fauna from western Seward Peninsula, Alaska: Quaternary Research, v. 4, p. 441-470, pls. 1-4, figs. 1-7.

Iqbal, Javed, 1973. Sedimentology and distribution of benthonic Foraminifera in M'Clure Strait (Canadian Arctic Archipelago): Halifax, Nova Scotia, Dalhousie Univ., unpub. master's thesis.

Ishiwada, Yasufumi, 1950, Foraminiferal death assemblages from the mouth of Toyama Bay (Studies on Recent marine sediments-No. 1) : Japan Geol. Survey Bull., v. 1, no. 4, p. 182-194, 1 pl.

Kiaer, Hans, 1899, Thalamophora: Norwegian North-Atlantic Exped., 1876-1878, Zoology, v. 7, no. 25, p. 1-13, pl. 1 , distrib, table.

Loeblich, A. R., Jr., and Tappan, Helen, 1953, Studies of Arctic Foraminifera: Smithsonian Misc. Colln., v. 121, no. 7, p. 1-150, pls. 1-24. 
1957, The foraminiferal genus Cruciloculina d'Orbigny, 1839, in Loeblich, A. R., Jr., and Collaborators, Studies in Foraminifera: U.S. Natl. Mus. Bull. 215, p. 233-235, pl. 74 .

Loeblich, A. R., Jr., Tappan, Helen, and others, 1964, Protista 2, Sarcodina, chiefly "Thecamoebians" and Foraminiferida, Part C of Moore, R. C., ed., Treatise on invertebrate paleontology: New York and Lawrence, Kans., Geol. Soc. America and Univ. Kansas Press, 2 v., 900 p., 653 figs.

Maync, Wolf, 1952, Critical taxonomic study and nomenclatural revision of the Lituolidae based upon the prototype of the family, Lituola nautiloidea Lamarck, 1804: Cushman Found. Foram. Research Contr., v. 3, p. 35-56, pls. 9-12, figs. A-C.

Nagy, Jenö, 1963, Foraminifera in some bottom samples from shallow waters in Vestspitsbergen: Norsk Polarinst. Arb. 1963, p. 109-127, pls. 1, 2, figs. 1-3, table 1.

Parker, F. L., 1952, Foraminifera species off Portsmouth, New Hampshire: Harvard Univ. Mus. Comp. Zoology Bull., v. 106, no. 9, p. 391-423, pls. 1-6.

-1954, Distribution of the Foraminifera in the northeastern Gulf of Mexico: Harvard Univ. Mus. Comp. Zoology Bull., v. 111, no. 10, p. 453-588, pls. 1-13.

-1962, Planktonic foraminiferal species in Pacific sediments: Micropaleontology, v. 8, no. 2, p. 219-254, pls. $1-10$.

Parr, W. J., 1950, Foraminifera: British, Australian and New Zealand Antarctic Research Exped. 1929-31, Repts., ser. B (Zoology and Botany), v. 5, pt. 6, p. 233-392, pls. 3-15, figs. $1-8$.

Phleger, F. B., Jr., 1952, Foraminifera distribution in some sediment samples from the Canadian and Greenland Arctic: Cushman Found. Foram. Research Contr., v. 3, p. $80-89$, pls. 13,14 , fig. 1 , table 1 .

Phleger, F. B., Jr., and Parker, F. L., 1951, Foraminifera species in Phleger, F. B., Jr., Pt. 2, Ecology of Foraminifera, northwest Gulf of Mexico: Geol. Soc. America Mem. 46, p. 1-64, pls. 1-20.

Rouvillois, Armelle, 1966, Contribution a l'étude micropaléontologique de la baie du Roi, au Spitzberg: Rev. Micropaléontologie, v. 9 , no. 3, p. 169-176, fig. 1 , tables $1,2$.

Slobodin, V. Ja., and Tamanova, S. V., 1972, Kompleksy Foraminifer iz donnykh otlozhenij Karskogo Morja i ikh Znachenie dlja izuchenija rezhima novejshikh dvizhenij, in Novejshaja Tektonika i paleogeografija Sovetskoj Arktiki v svjazi s otsenkoj mineral 'nykh Resursov. Sbornik Statei: Leningrad, Nauchno-Issled. Inst. Geologii Arktiki, p. 23-35, figs. 1-3, tables 1-7.

Stschedrina, Z. G., 1936, Zur Kenntnis der Foraminiferenfauna der Arktischen Meere der USSR: Leningrad, Vses. arkticheskii inst. Trudy, v. 33, p. 51-64, 1 table. -1938, On the distribution of Foraminifera in the Kara Sea: Akad. Nauk SSSR Doklady, new ser., v. 19, no. 4, p. $319-322$.

1946, New species of Foraminifera from the Arctic Ocean (in Russian with English summary) in Gorbunov, G. P., Articheskii Nauchno-Issled. Inst., Dreifuiushcheia Eksped. Glavsevmorputi na Ledokolnom Parokhode "G. Sedov" 1937-1940, Trudy [Transactions of the Arctic Scientific Research Inst. Northern Sea Route Board
Drifting Exped. on the Icebreaker "G. Sedov" in 19371940], v. 3 (Biology): Moscow-Leningrad, p. 143, 147, pl. 3.

1947, On the distribution of foraminifers in the Greenland Sea: Akad. Nauk. SSSR Doklady, new ser., v. 55, no. 9 , p. 859-862, tables 1,2 .

1958, Ob Iskopaemykh Foraminiferakh $\mathrm{v}$ donnykh Otlozhenijach Karskogo Morja Sbornik Statei: Leningrad. Nauchno-Issled. Inst. Geologii Arktiki, v. 11, p. 66-72, table 1 .

-1959 , The dependence of the distribution of Foraminifera in the seas of the U.S.S.R. on the environmental factors: Internat. Cong. Zoology, 15th, London 1958, Proc., sec. 3, paper 30, p. 218-221.

1962, Foraminifera of the White Sea bays in Zenkewitch, L. A., ed., Biology of the White Sea: Moscow State Univ., White Sea Biol. Sta., Repts., v. 1, p. 51-69, figs. 1-10. [In Russian.]

1964a, Foraminifery (Foraminifera) Severnoj Chasti Grenlandskogo Morja, in Nauchnye Rezul'taty Vysokoshirotnykh Okeanograficheskikh Ekspedithij v Severnuju Chast'Grenlandskogo Morja i Prilegajushchie Rajony Arkticheskogo Bassejna v 1955-1958 gg: Arkticheskogo i Antarkticheskogo Nauchno-issl. Inst., Glavnogo Uprav. Gidrometeorol. Sluzhby pri Sovete Ministrov SSSR, Trudy, v. 259, p. 120-142, tables 1-10.

1964b, Foraminifery (Foraminifera) Vysokikh Shirot Arkticheskogo Bassejna, in Nauchnye Rezul'taty Vysokoshirotnykh Okeanograficheskikh Ekspedithij v Severnuju Chast'Grenlandskogo Morja i Prilegajushchie Rajony Arkticheskogo Bassejna v 1955-1958 gg: Arkticheskogo i Antarkticheskogo Nauchno-issl. Inst. Glavnogo Uprav. Gidrometeorol. Sluzhby pri Sovete Ministrov SSSR, Trudy, v. 259, p. 79-119, pls. 1, 2, text figs. 1-4, table 1 .

Todd, Ruth, 1965, The Foraminifera of the tropical Pacific collections of the "Albatross," 1899-1900. Part 4.-Rotaliform families and planktonic families: U.S. Natl. Mus. Bull. 161, pt. 4, 139 p., 28 pls., 5 tables.

Todd, Ruth, and Low, Doris, 1961, Near-shore Foraminifera of Martha's Vineyard Island, Massachusetts: Cushman Found. Foram. Research Contr., v. 12, p. 5-21, pls. 1, 2, figs. 1, 2, table 1 .

1966, Foraminifera from the Arctic Ocean off the eastern Siberian coast, in Geological Survey research 1966: U.S. Geol. Survey Prof. Paper 550-C, p. C79-C85, fig. 1, tables 1-4.

1967, Recent Foraminifera from the Gulf of Alaska and southeastern Alaska: U.S. Geol. Survey Prof. Paper 573-A, 46 p., 5 pls., 1 fig., 2 tables.

Uchio, Takayasu, 1960, Ecology of living benthonic Foraminifera from the San Diego, California, area: Cushman Found. Foram. Research Spec. Pub. 5, 72 p., 10 pls., 18 figs., 9 tables.

Vilks, Gustavs, 1969, Recent Foraminifera in the Canadian Arctic: Micropaleontology, v. 15, p. 35-60, pls. 1-3, figs. 1-5, tables 1-4.

Walton, W. R., 1964, Recent foraminiferal ecology and paleoecology, in Imbrie, John, and Newell, Norman, eds. Approaches to paleoecology: New York, John Wiley and Sons, Inc., p. 151-237, figs. 1-31. 



\section{INDEX}

\section{A \\ Page}

abyssorum, Rhabdammina 18, 19, 25; pl. acuta, Jaculella $18,19,23$,; pI. Adercotryma glomeratum 16, 17, 18, 19, 21; pl. 1 advena, Eggerella _............. 16, 17, 18, 22 akneriana, Quinqueloculina _.... 15, 18, 19, 24 Alveolophragmium karaensis _........ 17 Ammodiscus gullmarensis _... 18, 19, 21; pI. Angulogerina fluens ................ 18, 19, 21 arborescens, Hyperammina Psammatodendron .......... 14, 18, 19, 24 arctica, Elphidiella _.............. 19, 22 Reophax _. 18,24 Robertina _............... 18, 25 Turrispirillina Aschemonella scabra _... 1, 16, 18, 19, 21; pl. Astacolus planulatus _................ 19, 21 Astrononion gallowayi _...... $14,15,18,19,21$ Astrorhiza

crassatina atlantica, Proteonina _............. 17 auriculata, Globobulimina ............ 18, 23

\section{$\mathbf{B}$}

baggi, Dentalina.

$18,19,22$ bartletti, Elphidium _............. 15, 18, 22 Bathysiphon -..................... 24 biformis, Spiroplectammina $18,19,25$

Biloculinella globula Bolivina rhomboidalis ............... 19,21 bradii, Cibicides .............. 12, 18, 19, 21 Planulina

bradyi, Cribrostomoides _............. 22 Hyperammina _................ 17 Placopsilina _.................. 18, 24

Buccella frigida _............... 15, 16 inusitata -

bucculenta, Triloculina _........... 14

bucculentus, Planispirinoides _- 16, 18, 24; pl. Bulimina exilis _............... 18, 21; pl. 2 bulla, Tholosina _................. 15

bullata, Trochamminella -....... 17 bulloides, Globigerina _.............. 18, 23 Pullenia _.................... 18, 19, 24

\section{C}

canariense, Haplophragmium _....... 14 Cassidella complanata Cassidulina _....................... 16, 23 crassa - islandica _... laevigata -...- 14 norcrossi _.............. 15, 17, 18, 19, 21 subglobosa _..._...... 19, 21 teretis -

Cibicides _........................... 13, 14, 16 bradii $12,18,19,21$ lobatulus -_... 14, 15, 18, 19, 21 rotundatus _........... rugasa sp $\ldots$
Clevatum, Elphidium $-2,14,15,16,17,14$ $16,17,18,19,22$ complanata, Cassidella .............. 21 Virgulina

conica, Trochammina 18, 19, 25 contortus, Recurvoides _..... 22 Cornuspira involvens ........ 14, 18, 21; pl. 2 lacunosa _................ 19, 21; pl. 2 planorbis _................... 18, 21 corrugata, Patellina crassa, Cassidulina $\ldots . . . . . . . . . . .15$ crassatina, Astrorhiza Psammosiphonella _........... 18, 19, 24 crassimargo, Cribrostomoides _- 1, 16, 18, 19, 22 Labrospira

Cribrostomoides _... 17, 21, 22 bradyi ........................ 22 crassimargo _............. 1, 16, 18, 19, 22 jeffreysi _............ 14, 18, 19, 22; pl. 1 subglobosum

subglobosus _... 1, 12, 18, 21, 22; pl. 1 Cruciloculina ericsoni _............ 18, 22; pl. 2 cylindrica, Pelosina _..... 16, 18, 19

\section{D}

decepta, Dentalina _............... 19, 22 Dentalina baggi _............. 18, 19, 22 decepta $\ldots \ldots \ldots . .19,22$ frobisherensis _._._........... 18, 19, 22 dentaliniformis, Reophax _....... 14, 18, 24 diffugiformis, Proteonina _......... 16 Reophax Saccammina digitata, Nonionella turgida _..._..... 18, 24 discreta, Rhabdammina _..... 18, 19, 25; pl. 1 distoma, Lagena _..... 19, 24

\section{$\mathbf{E}$}

earlandi, Textularia $18,19,25$ Eggerella advena elongata, Hyperammina .... 1, 12, 14, 18, 19,

23; pl. 19,22 hannai _......................... 18, 22

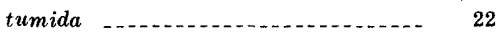

Elphidium _... 15, 16 bartletti _... clavatum frigidum _.................. 18, 19, 22 incertum crbiculare _.............. 16, 18, 19, 22 Epistominella exigua _..._... 12, 19, 22; pl. 2 Eponides repandus _. 19,22 tener _.......... 12, 15, 18, 19, 22; pl. tumidulus horvathi .... 12, 15, 19, 22; pl. 2 ericsoni, Cruciloculina _......... 18, 22; pl. 2 exigua, Epistominella _..._-. 12, 19, 22; pl. 2 exilis, Bulimina _............ 18, 21; pl. 2

\section{$\mathbf{F}$}

Fischerina sp
Page

Fischerinella fissuraperta, Trochamminula -------- 17 Fissurina kerguelenensis _..... 12, 18, 19, 23; pl. 2 marginata _... 18, 19, 23 serrata _...... flatulenta, Lagena Florilus _._......... 16, 17 labradoricus _............ 14, 18, 19, 23 fluens, Angulogerina _............. 18, 19, 21 fornasinii, Pyrgo _............... 18, 24; pl. 2 friabilis, Hyperammina $\ldots . . . \ldots . .18,19,23$

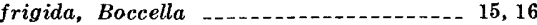
frigidum, Elphidium _............. 18, 19, 22 frobisherensis, Dentalina -_._._-_. 18, 19, 22 fusca, Psammosphaera _.... 1, 12, 16, 18, 22, 24

\section{G}

gallowayi, Astrononion -...-. 14, 15, 18, 19, 21 glacialis, Globulina -........ 18, 23 Globigerina ...................... 16 bulloides _... pachyderma _........... 12, 16, 18, 21, 23 quinqueloba _............... 19, 23 Globigerinita glutinata _-_........-_ 18, 23 Globobulimina auriculata _..._....... 18, 23 globula, Biloculinella _............... 18, 21 globularis, Rosalina _._._. 18, 25 Globulina glacialis _................. 18, 23 glomeratum, Adercotryma 16, 17, 18, 19, 21; pl. 1 glutinata, Globigerinita _-_._..... 18, 23 grisea, Trochammina _..... 14, 18, 19, 25; pl. 1 groenlandica, Parafissurina _-. 12, 19, 24; pl. 2 gullmarensis, Ammodiscus _... 18, 19, 21; pl. 1 guttifer, Reophax ....... 18, 19, 23, 25; pl. 1

\section{H}

hannai, Elphidiella _................ 18, 22 Haplophragmium canariense ......... 14 latidorsatum _................ 22 nanum _...................... 14, 25 Haplophragmoides -_. 16, 22 sp _......... 15, 16 hauerinoides, Pateoris .......... 15, 18, 24 helenae, Islandiella ........... 14, 18, 19, 23 Hemisphaerammina ............... 23 marisalbi _..................... 18, 23 hexagona, Oolina _............... 19, 24 hispidula, Lagena _.............. 18, 19, 24 Hormosina sp ............... 18, 19, 23; pl. 1 horvathi, Eponides tumidulus _...- 12,15,19, $22 ;$ pl. 2 Stetsonia _. 12, 19, 25 hyalascidea, Laryngosigma _....... 18, 24; pl. 2 Hyperammina -...........- 23 arborescens _................ 14 bradyi _._. elongata _....... 1, 12, 14, 18, 19, 23; pl. 1 friabilis _...... 18, 19, 23

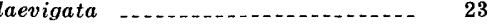
ramosa 


$\begin{array}{lr}\text { I } & \text { Page } \\ \text { incertum, Elphidium } & \\ \text { inusitata, Buccella } & \\ \text { involvens, Cornuspira } & \\ \text { Iridia marisalbi } & \\ \text { Iridiella } & \\ \text { islandica, Cassidulina } & \\ \quad \text { Islandiella } & 23 \\ \text { Islandiella } & \\ \quad \text { helenae } & \\ \quad \text { islandica } & \end{array}$

\section{$\mathbf{J}$}

Jaculella japonica, Trochammina _.... 18, 19, 25; pl. 1 jeffreysi, Cribrostomoides _- 14, 18, 19, 22; pl. 1

\section{$\mathbf{K}$}

karaensis, Alveolophragmium -_-_- 17 karica, Trochammina _.......... 16, 17, 25 kerguelenensis, Fissurina _... 12, 18, 19, 23; pl. 2

L

labradorica, Nonionellina

17 labradoricus, Florilus _-_._-_... 14, 18, 19, 23 Labrospira crassimargo _-..-_-_-_- 17 lacunosa, Cornuspira _-_._-_._. 19, 21; pl. 2 laevigata, Cassidulina _........... 14 Hyperammina -.............. 23 laevigatum, Recurvoides _....... 17, 18, 19, 24 laevis, Lagena _..................... 18, 24; pl. 2 Lagena distoma .................. 19, 24 flatulenta hispidula _................. 18, 19, 24

laevis _._. Laryngosigma hyalascidea _..... 18, 24; pl. 2 latidorsatum, Haplophragmium _....- 22 Lenticulina -... 21 lineata, Oolina ................... 19, 24 lobata, Trochammina lobatulus, Cibicides _.........14, 15, 18, 19, 21 Truncatulina ..................... 13

\section{M}

marginata, Fissurina _........... 18, 19, 23 marisalbi, Hemisphaerammina _...... 18, 23 Iridia Marsipella melo, Oolina Melonis zaandamae .......... 18, 19, 24; pl. 2 Miliolinella

\section{$\mathbf{N}$}

nana, Trochammina $\ldots . .1,12,14,15,16,17,18$, 19,$25 ; \mathrm{pl} .1$

nanum, Haplophragmium _......... 14, 25 nitida, Trochammina nodulosus, Reophax $\ldots \ldots 1,12,18,19,25 ; \mathrm{pl} .1$ Nonion zaandamae .................. 24

Nonionella turgida digitata _.......... 18, 24

Nonionellina

$$
\text { labradorica }
$$

stelligera -......... 14 norcrossi, Cassidulina $\ldots \ldots . . .15,17,18,19,21$ $\mathbf{0}$

Oolina hexagona lineata

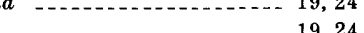
melo orbiculare, Elphidium $\ldots \ldots . .16,18,19,22$ $\mathbf{P}$

pachyderma, Globigerina _... 12, 16, 18, 21, 23 papillata, Thurammina _...... 18, 25; pl. 1 Parafissurina _................... 19 groenlandica tectulostoma _- sp Patcllina corrugata Pateoris hauerinoides _............ 15, 18, 24 Pelosina cylindrica _._._._._._._. 16, 18, 19 sp Placopsilina bradyi _................ 18,24 Planispirina sphaera Planispirinoides bucculentus _- 16, 18, 24; pl. 2 planorbis, Cornuspira _._._._._._. 18, 21 planulatus, Astacolus Planulina bradii wuellerostorfi

Polystomella striatopunctata

Proteonina atlantica diff ugiformis

Protoschista sp _. Psammatodendron arborescens _. 14, 18, 19, 24

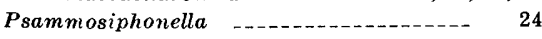
crassatina _............... 18, 19, 24 Psammosphaera fusca .... 1, 12, 16, 18, 22, 24 Pseudononion sp ................... 19, 24 Pullenia bulloides ....... 18, 19, 24 pusilla, Trochammina _............ 25

Pyrgo fornasinii _..._......... 18, 24; pl. 2 rotalaria _... vespertilio _..._._. 12, 16, 18, 19, 24; pl. 2 williamsoni _.............. 18, 24; pl. 2 Pyrgoella sphaera

\section{$\mathbf{Q}$}

quadriloba, Trochammina _-_-_-_- 18, 19, 25 quinqueloba, Globigerina _........... 19, 23 Quinqueloculina akneriana $\ldots . . . .15,18,19,24$ sp -_-_-_._. 16

\section{$\mathbf{R}$}

ramosa, Hyperammina _-_._._._._.-. 25 Saccorhiza _.... 1, 12, 15, 18, 19, 25; pl. 1

Recurvoides _..................... 22

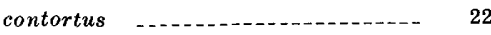
laevigatum _.............. 17, 18, 19, 24 subglobosus

Reophax arctica _.............. 18, 24 dentaliniformis ............... 14, 18, 24 diffugiformis guttifer nodulosus $\ldots \ldots \ldots \ldots 1,12,18,19,25 ; \mathrm{pl} .1$ scorpiurus $\quad--1,12,14,16,17,18,19,24,25$ repandus, Eponides _............... 19, 22 Rhabdammina _................. 24 abyssorim .......... 12, 13, 14, 16, 17, 18 19,$25 ; \mathrm{pl} .1$ discreta _............... 18, 19, 25; pl. 1 rhomboidalis, Bolivina _............. 19, 21 Robertina arctica _._._-_._._. 18, 25 Rosalina globularis ........ 18, 25 rotalaria, Pyrgo _............. 19, 24; pl. 2 rotundatus, Cibicides _....... 15 rugosa, Cibicides
$\mathbf{S}$

Page

Saccammina difflugiformis $\ldots \ldots \ldots \ldots 18,19,25$ sphaerica _........... 12, 13, 18, 24, 25 Saccorhiza ramosa .... 1, 12, 15, 18, 19, 25; pl. scabra, Aschemonella $-.-1,16,18,19,21 ;$ pl. scapha, Nonionina _.................. 14 schaudinni, Tolypammina _...... 19, 25; pl. 1 scorpiurus, Reophax _.... 1, 12, 14, 16, 17, 18, $19,24,25$ Scutuloris serrata, Fissurina _............... 18, 23 sphaera, Planispirina _.......... 14

Pyrgoella _._._._._._. 14, 18, 24; pl. 2 sphaerica, Saccammina -...- 12, 13, 18, 24, 25 Spirillina vivipara Spiroplectammina biformis $15,16,17,18,19,25$ stelligera, Nonionina Stetsonia horvathi _............... 12, 19, 25 striatopunctata, Polystomella _-.._-_. 14 subglobosa, Cassidulina _............. 19, 21 subglobosum, Cribrostomoides _....... 22 subglobosus, Cribrostomoides _... 1, 12, 18, 21,

Recurvoides 22; pl. 1

\section{$\mathbf{T}$}

tectulostoma, Parafissurina _... 12, 19, 24; pl. 2 tener, Eponides _....... 12, 15, 18, 19, 22; pl. 2 teretis, Cassidulina Textularia earlandi torquata _......... 17, 18, 19, 25; pl. 1 Tholosina bulla Thurammina papillata Tolypammina schaudinni _........ 19, 25; pl. 1 torquata, Textularia _.... 17, 18, 19, 25; pl. 1 trihedra, Triloculina _... 12, 15, 18, 19, 25; pl. 2 Triloculina bucculenta ......... 14 trihedra _........ 12, 15, 18, 19, 25; pl. 2

Trochammina _........ 14, 16, 18, 19, 25; p1, 1 conica -................ 18, 19, 25 grisea _............. 14, 18, 19, 25; pl. 1 japonica _............... 18, 19, 25; pl. 1 kariea _... lobata - _.. nana _. $1,12,14,15,16,17,18,19,25 ; \mathrm{pl} .1$ nitida -................ 14 pusilla quadriloba _..._. sp _.

Trochamminella bullata

Trochamminula fissuraperta _........ 17

Truncatulina lobatulus .............. 13 tumidulus _._........... 23 tumida, Elphidiella tumidulus horvathi, Eponides _-..-- 12,15,19, 22; pl. 2

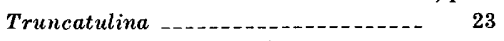
turgida digitata, Nonionella _....... 18, 24 Turrispirillina arctica _............. 19, 25

\section{V}

vespertilio, Pyrgo _.... 12, 16, 18, 19, 24; pl. 2 Virgulina complanata vivipara, Spirillina _...... 18, 25 $\mathbf{W}$

Webbinella _.................... 23 williamsoni, Pyrgo wuellerstorfi, Planulina

$\mathbf{Z}$

zaandamae, Melonis _........ 18, 19,24; pl. 2 Nonion 


\section{PLATES 1 AND 2}

Contact photographs of the plates in this report are available, at cost, from U.S.

Geological Survey Library, Federal Center, Denver, Colorado 80225 


\section{PLATE 1}

Figure 1. Trochammina cf. T. grisea Earland (p. 21).

USNM 241897, $\times 80$; Kara Sea, sta. 77. $a$, Dorsal view; $b$, ventral view.

2. Trochammina cf. T. japonica Ishiwada (p. 21).

USNM 241898, $\times 80$; Kara Sea, sta. 77. $a$, Dorsal view; $b$, ventral view; $c$, edge view.

3. Cribrostomoides jeffreysi (Williamson) (p. 18).

USNM 241900, $\times 30$; Kara Sea, sta. 102. $a$, Side view; $b$, edge view.

4. Ammodiscus gullmarensis Höglund (p. 17).

USNM 241921, $\times 50$; Greenland Sea, sta. 5 .

5, 6. Trochammina nana (Brady) (p. 21).

5. USNM 241899, $\times 80$; Kara Sea, sta. 77. $a$, Dorsal view; $b$, ventral view.

6. USNM 241913, $\times 80$; Kara Sea, sta. 143. $a$, Dorsal view; $b$, ventral view.

7. Cribrostomoides subglobosus (G. O. Sars) (p. 18).

USNM 241920, $\times 30$; Greenland Sea, sta. 4. Edge view to show aperture.

8. Adercotryma glomeratum (Brady) (p. 17).

USNM 241929, × 50; Greenland Sea, sta. 30.

9. Tolypammina schaudinni Rhumbler (p. 21).

USNM 241914, × 50; Greenland Sea, sta. 2.

10. Thurammina papillata Brady (p. 21).

USNM 241909, $\times 30$; Kara Sea, sta. 135. Broken specimen.

11. Textularia torquata Parker (p. 21).

USNM 241896, × 80; Kara Sea, sta. 77.

12. Rhabdammina discreta Brady (p. 21).

USNM 241926, × 15; Greenland Sea, sta. 23.

13,19. Rhabdammina abyssorum M. Sars (p. 21).

13. USNM 241910, $\times 15$; Kara Sea, sta. 137 .

19. USNM 241911, $\times 15$; Kara Sea, sta. 137 .

14. Reophax guttifer Brady (p. 21).

USNM 241906, × 50; Kara Sea, sta. 109.

15. Hormosina sp. of Parker, 1952 (p. 19).

USNM 241915, $\times 50$; Greenland Sea, sta. 2.

16. Reophax nodulosus Brady (p. 21).

USNM 241895, $\times 15$; Kara Sea, sta. 77 .

17. Jaculella acuta Brady (p. 19).

USNM $241890, \times 15$; Kara Sea, sta. 1 .

18. Hyperammina elongata Brady (p. 19).

USNM 241894, $\times 15$; Kara Sea, sta. 77.

20. Aschemonella scabra Brady (p. 17).

USNM 241912, × 15; Kara Sea, sta. 141.

21, 22. Saccorhiza ramosa (Brady) (p. 21).

21. USNM 241891, $\times 7$; Kara Sea, sta. 41.

22. USNM 241925, $\times 15$; Greenland Sea, sta. 19. 


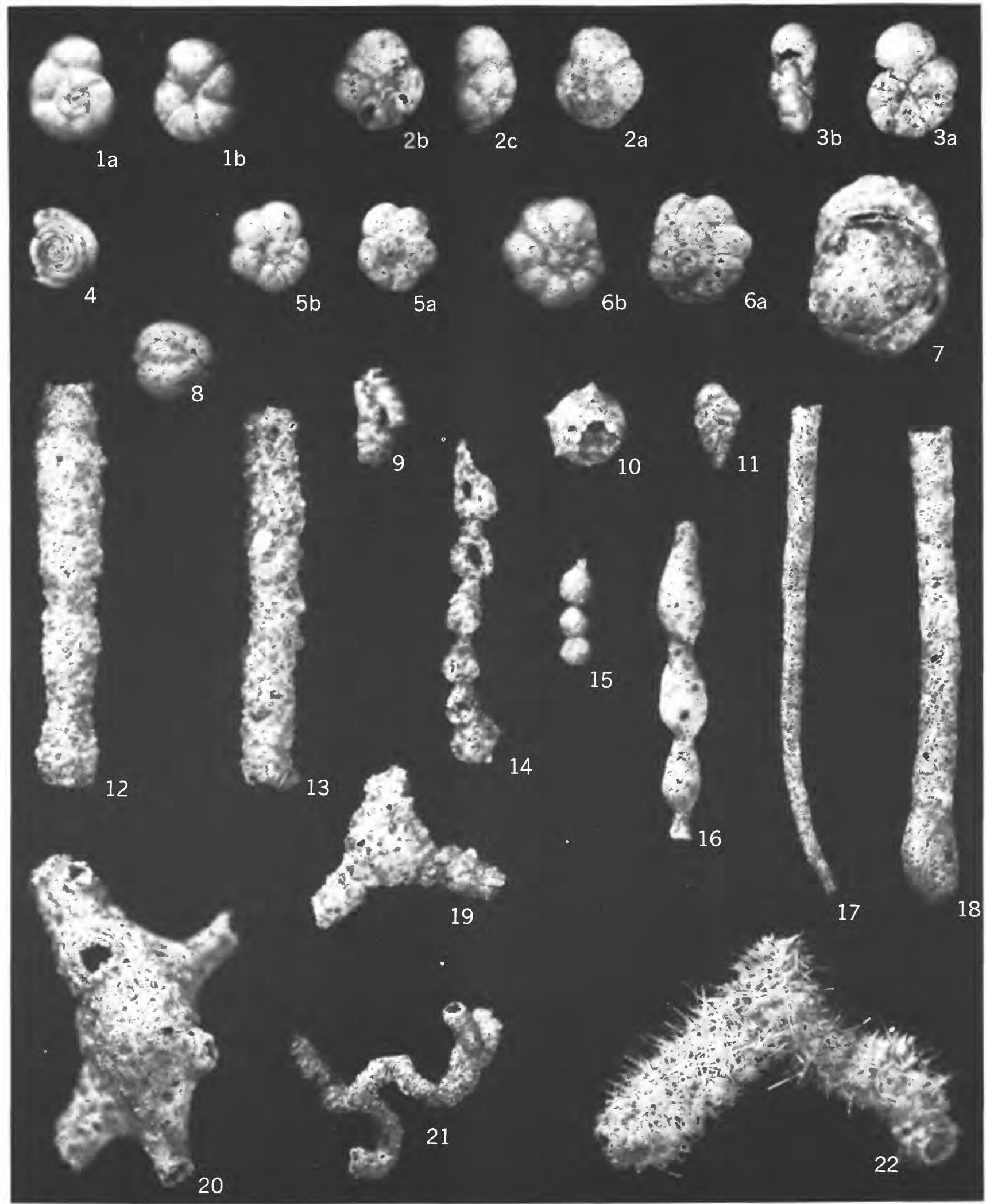

ARENACEOUS FORAMINIFERA FROM KARA AND GREENLAND SEAS 


\section{PLATE 2}

Figure 1. Lagena laevis (Montagu) (p. 20).

USNM 241892, × 30; Kara Sea, sta. 53.

2. Laryngosigma hyalascidia Loeblich and Tappan (p. 20). USNM 241905, × 50; Kara Sea, sta. 106.

3. Bulimina exilis Brady (p. 17). USNM 241893, $\times$ 50; Kara Sea, sta. 53.

4. Parafissurina sp. (p. 20). USNM 241924, $\times$ 30; Greenland Sea, sta. 13. $a$, Front view; $b$, side view.

5. Parafissurina tectulostoma Loeblich and Tappan (p. 20). USNM 241931, × 50; Greenland Sea, sta. 33.

6. Parafissurina groenlandica Stschedrina (p. 20). USNM 241932, $\times$ 50; Greenland Sea, sta. 33. $a$, $b$, Views $90^{\circ}$ apart.

7. Eponides tumidulus horvathi Green (p. 19). USNM 241923, $\times 80$; Greenland Sea, sta. 11. $a$, Dorsal view; $b$, ventral view; $c$, edge view.

8. Melonis zaandamae (van Voorthuysen) (p. 20). USNM 241928, $\times$ 30; Greenland Sea, sta. 30. $a$, Side view; $b$, edge view.

9. Fissurina kerguelenensis Parr (p. 19). USNM 241917, × 80; Greenland Sea, sta. 3 .

10. Eponides tener (Brady) (p. 19). USNM 241919, $\times$ 80; Greenland Sea, sta. 3. $a$, Dorsal view; $b$, ventral view; $c$, edge view.

11. Epistominella exigua (Brady) (p. 18). USNM 241918, $\times$ 80; Greenland Sea, sta. 3. $a$, Dorsal view; $b$, ventral view; $c$, edge view.

12. Fischerina sp. (p. 19). USNM 241930, × 50; Greenland Sea, sta. 32. $a$, Dorsal view; $b$, ventral view; $c$, edge view.

13. Cruciloculina ericsoni Loeblich and Tappan (p. 18). USNM 241908, $\times$ 30; Kara Sea, sta. 112. Apertural view.

14. Pyrgo williamsoni (Silvestri) (p. 20). USNM $241907, \times 30$; Kara Sea, sta. $110 . a$, Front view; $b$, side view.

15. Tritoculina trihedra Loeblich and Tappan (p. 21). USNM 241916, × 50; Greenland Sea, sta. 3.

16. Pyrgo fornasinii Chapman and Parr (p. 20). USNM 241904, $\times 15$; Kara Sea, sta. 106. $a$, Front view; $b$. top view.

17. Planispirinoides bucculentus (Brady) (p. 20). USNM 241903, $\times 15$; Kara Sea, sta. 106. $a$, Front view; $b$, side view.

18. Cornuspira involvens (Reuss) (p. 17). USNM 241901, × 15; Kara Sea, sta. 106. $\alpha$, Side view; $b$, edge view.

19. Cornuspira lacunosa Brady (p. 17). USNM 241927, × 15; Greenland Sea, sta. 29.

20. Pyrgo rotalaria Loeblich and Tappan (p. 20).

USNM 241933, $\times$ 30; Greenland Sea, sta. 37. Top view.

21. Pyrgo vespertitio (Schlumberger) (p. 20).

USNM 241922, × 15; Greenland Sea, sta. 6. Top view.

22. Pyrgoella sphaera (d'Orbigny) (p. 20).

USNM 241902, × 15; Kara Sea, sta. 106. Top view. 

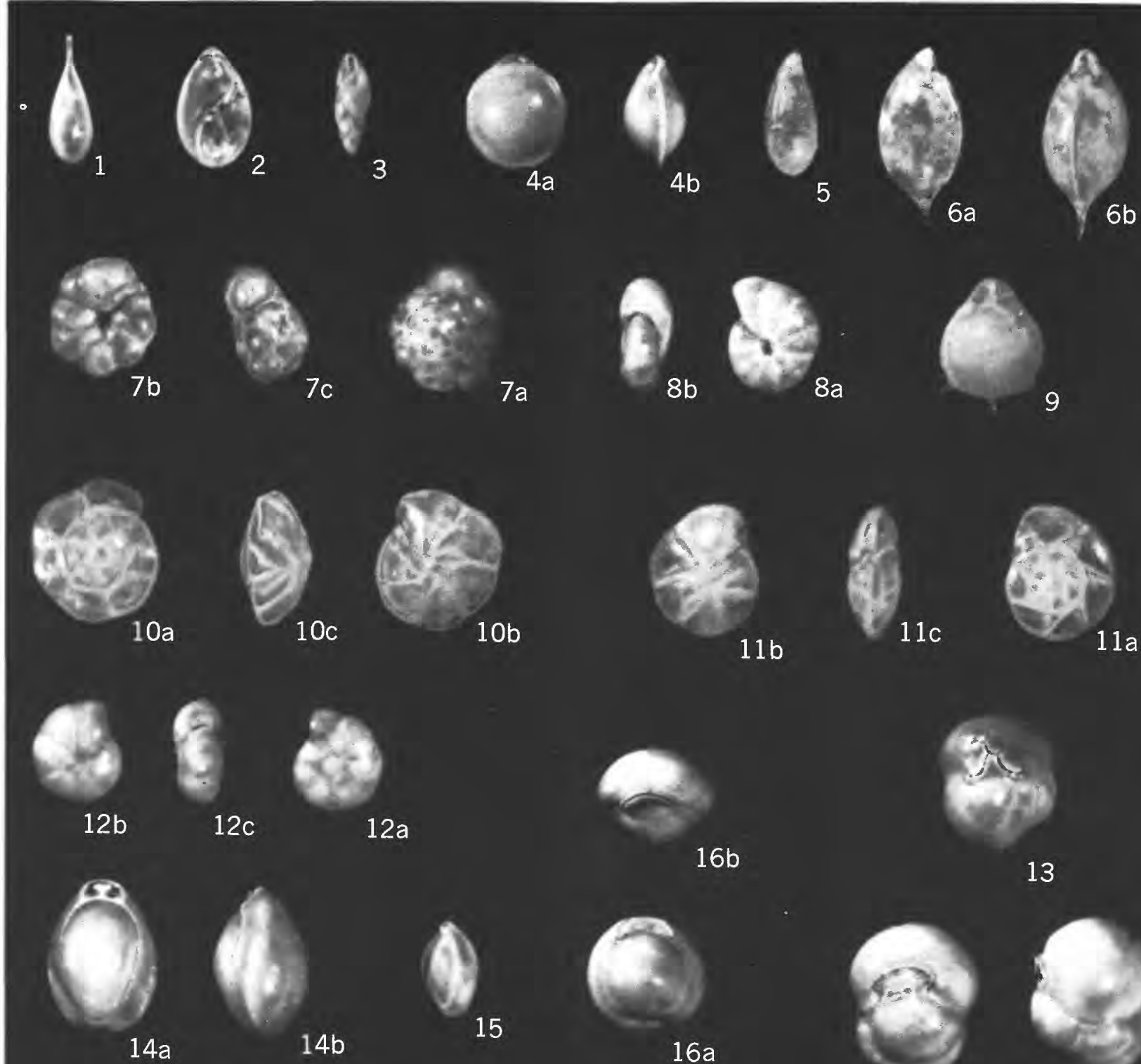

$16 b$

13
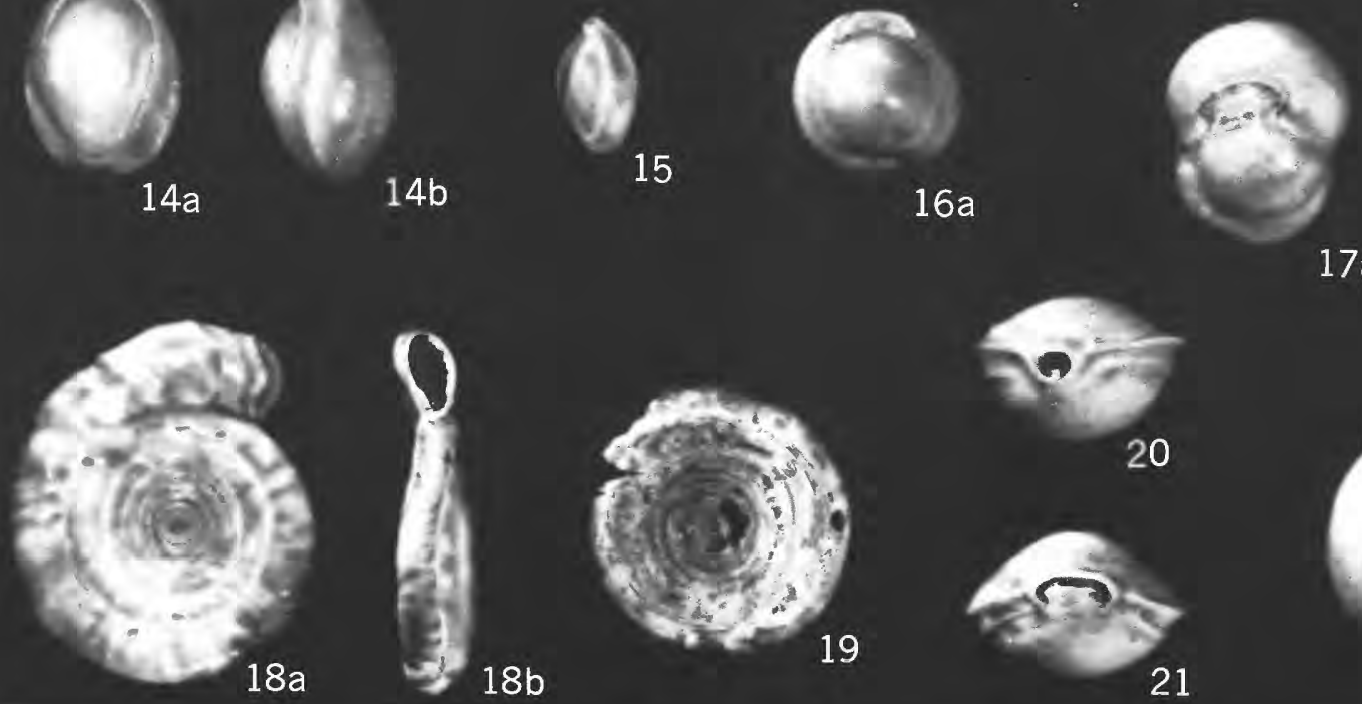

$17 a$

$17 b$

CALCAREOUS FORAMINIFERA FROM KARA AND GREENLAND SEAS 